\title{
A nem öngyilkossági szándékkal történó önsértés komplex felmérése - a Kezelésközpontú Önsértés Kérdőív (SIQ-TR) magyar adaptációja
}

\author{
REINHARDT MELINDA ${ }^{1,2 *}$ - DRUBINA BOGLÁRKA ${ }^{1,3}-$ \\ HORVÁTH ZSOLT ${ }^{1,3}$ - KÖKÖNYEI GYÖNGYI ${ }^{1,4,5}$
}

\author{
${ }^{1}$ ELTE Eötvös Loránd Tudományegyetem Pszichológiai Intézet, Budapest \\ ²Zuglói Egészségügyi Szolgálat, Gyermek-, és Serdülőpszichiátria, Budapest \\ ${ }^{3}$ ELTE Eötvös Loránd Tudományegyetem Pszichológiai Doktori Iskola, Budapest \\ ${ }^{4}$ SE-NAP 2 Genetikai Agyi Képalkotó Migrén Kutatócsoport, MTA, \\ Semmelweis Egyetem, Budapest \\ ${ }^{5}$ Semmelweis Egyetem, Gyógyszerhatástani Intézet, Budapest
}

(Beérkezett: 2019. október 23.; elfogadva: 2020. január 8.)

Elméleti háttér: A nem öngyilkossági szándékkal történő önsértő viselkedés (pl. a saját test szándékos megvágása, megütése, megharapása) egyre növekvő mértékú magatartási és egészségügyi probléma a serdülők körében. Felmérésére többféle mérőeszköz született, de kevés olyan létezik, amely a jelenséget annak komplexitásában ragadja meg. Cél: Vizsgálatunk célja a különböző önsértő viselkedésformákat több szempontból (pl. attitüdinális komponensek, kapcsolódó érzelmek, a háttérben meghúzódó okok) felmérő Kezelésközpontú Önsértés Kérdőív (Self-Injury Questionnaire-Treatment Related; SIQ-TR) bevezetése a hazai tesztállományba. Módszerek: A méróeszköz pszichometriai jellemzóit egy speciális populációban, 14 és 20 év közötti (átlagéletkor = 16,99 év; SD =1,28 év) fiatal fogvatartottak körében mértük be. A 244 fós javítóintézeti minta 92,6\%-a $(n=226)$ fiú volt. Az önsértéssel összefüggésben a negatív életeseményeket (Serdülő Életesemény Kérdőív) és az elkerülés-fókuszú érzelemregulációs mechanizmusokat (Tapasztalati Elkerülés Kérdőív; Serdülő Disszociatív Tapasztalatok Skála) is feltártuk. Eredmények: A javítóintézeti fiatalok 26,2\%-a $(n=64)$ aktuálisan is végez önsértő viselkedést, 34,4\%-uk $(n=84)$ esetében az önsértés az egy hónapnál korábbi élettörténetben jelent meg, a fennmaradó 39,3\% $(n=96)$ saját bevallása szerint sohasem folytatott önsértést. Eredményeink szerint a karmoláshoz és az ütéshez asszociálódik a legtöbb negatív érzelem, e két mód esetében a legerőteljesebb az arra irányuló figyelem, illetve azt követően a sebekről való öngondoskodás mértéke. Továbbá a karmolás és az ütés az a két önsértési mód, amelynek legjellemzőbb célja a negatív érzelmi állapotok csökkentése. A mintában a jelenleg és a korábban önsértők szignifikánsan több negatív életeseményt éltek át a megelőző fél évben a sohasem önsértőkhöz képest $(F(2)=9,16 ; p<0,0001)$. Az aktuálisan önsértők jellemezhetók

\footnotetext{
* Levelező szerző: Dr. Reinhardt Melinda, ELTE Eötvös Loránd Tudományegyetem Pedagógiai és Pszichológiai Kar, Pszichológiai Intézet, Klinikai Pszichológia és Addiktológia Tanszék, 1064, Budapest, Izabella u. 46. E-mail: reinhardt.melinda@ppk.elte.hu
} 
továbbá a legmagasabb disszociatív élményszinttel $(F(2)=7,82 ; p=0,001)$ és kognitív inflexibilitással $(F(2)=6,58 ; p=0,002)$. Következtetések: A Kezelésközpontú Önsértés Kérdőív magyar nyelvú változata (SIQ-TR-HU) hatékony eszköze a nem öngyilkossági szándékkal történő önsértés összetett vizsgálatának, ezzel összefüggésben célzott terápiás intervenciók megalapozását támogathatja.

Kulcsszavak: nem öngyilkossági szándékkal történő önsértés; Kezelésközpontú Önsértés Kérdőív; kérdőív-adaptáció; pszichometriai jellemzők; javítóintézeti minta

\section{Bevezetés}

A nem öngyilkossági szándékkal történő önsértés (non-suicidal self-injury, NSSI) a saját test felületének szándékos megsértését jelenti, amely különféle módokon történhet (Claes \& Vandereycken, 2007a), így például a saját testfelület szándékos megvágásával, megégetésével, megütésével, megharapásával vagy megkarmolásával. Fontos, hogy mindezt a személy öngyilkossági szándék nélkül teszi. Több szerző (pl. Claes \& Vandereycken, 2007b) szerint az NSSI-cselekedetek további kritériuma, hogy azok szociálisan nem elfogadott viselkedésminták.

A szándékos önsértés jelensége egy rendkívül összetett kategória, ahogyan a leírására és rendszerezésére megalkotott szakkifejezések is többfélék. Az angol nyelvú szakirodalomban az NSSI mellett gyakorta használják a deliberate self harm (DSH, szándékos önártalom; Pattison \& Kahan, 1983), a self-injurious behavior (SIB, önsértő viselkedés; pl. Nock, Joiner, Gordon, Lloyd-Richardson, \& Prinstein, 2006) vagy a pathological self-mutilation (PSM, kóros öncsonkítás; Favazza \& Rosenthal, 1993) kifejezéseket is. A DSH terminusába hagyományosan besorolják az öngyilkossági szándékú viselkedéseket is (Pattison \& Kahan, 1983), ahogyan a SIB ernyőfogalma is magában foglalja az NSSI viselkedéseket, az öngyilkossági kísérleteket és az öngyilkosságot (Hamza, Stewart, \& Willoughby, 2012). A mentális zavar tüneteként és különálló kórformaként is értelmezhetó PSM esetében a saját testfelület szándékos roncsolásáról beszélhetünk tudatos öngyilkossági szándék nélkül (Favazza \& Rosenthal, 1993). A PSM-be háromféle viselkedésforma sorolható: (1) jelentős, azonban ritka cselekmények, amelyek eróteljes károsodást eredményeznek a testen, és általában pszichotikus állapothoz vagy akut intoxikációhoz kapcsolódnak; (2) sztereotipikusan és ritmikusan ismétlődő önkárosító viselkedések, amelyek főként mentális retardáció kapcsán fordulnak elő és (3) felületes vagy közepes mértékú önsértő cselekedetek, mint a vágás, égetés vagy karmolás, amelyek számos mentális betegséggel társulhatnak. Utóbbi formát Favazza és Rosenthal (1993) az impulzuskontroll-nehézségekkel kapcsolták össze és kiemelték gyakori előfordulását személyiségzavarokban. Az NSSI fogalma a PSM har- 
madik csoportjához áll a legközelebb, s része a DSH és a SIB átfogóbb kategóriáinak. Az NSSI cselekedeteket egyértelmúen elkülöníthetjük az öngyilkossági kísérletektől és a befejezett öngyilkosságtól (Zetterqvist, 2015), ugyanakkor a SIB-viselkedések két formája - az NSSI és az öngyilkossági szándékú cselekedetek - gyakorta együtt is előfordulhatnak, bár kapcsolatuk nem egyértelmúen tisztázott a szakirodalomban. Számos kutatás (pl. Andover \& Gibb, 2010) felveti az NSSI rizikótényező szerepét az öngyilkos viselkedésben.

Az NSSI jelentős és növekvő mértékủ magatartási probléma fóként a serdülők (pl. In-Albon, Ruf, \& Schmid, 2013; Jacobson \& Gould, 2007; LloydRichardson, Perrine, Dierker, \& Kelley, 2007) és a fiatal felnőttek (pl. Saraff \& Pepper, 2014) körében. Normatív felnőtt populációban is 1-4\% közé teszik az előfordulási gyakoriságát (Briere \& Gil, 1998; Klonsky, 2011; Klonsky, Oltmanns, \& Turkheimer, 2003). Gyakori jelenség továbbá pszichés problémákkal küzdők esetében (pl. Washburn, Potthoff, Juzwin, \& Styer, 2015). A DSM-IV-TR-ben (APA, 2000) az önsértó és öngyilkos viselkedés a borderline személyiségzavar egyik meghatározó tüneteként szerepel. A DSM-5 függelékében (APA, 2013) továbbá megtalálható egy új kategória, az ún. nem öngyilkossági szándékú önsértés zavar (Non-suicidal self-injury disorder, NSSID) is. NSSI-cselekedetek azonban önmagukban - borderline karakterisztikumok és NSSID nélkül - is megjelenhetnek. A jelenségkör vizsgálata azért is különösen fontos, mert további testi és pszichológiai problémákat, akár komoly egészségkárosodást is eredményezhet (Veague, Collins, \& Levitt, 2008), illetve az önsértés számos diszfunkcionális múködésmóddal (pl. maladaptív érzelemreguláció; Houben és mtsai, 2016; Zelkowitz, Porter, Heiman, \& Cole, 2017) és pszichés problémával (pl. Victor \& Klonsky, 2014) asszociálódik, valamint rizikófaktora lehet a szuicid viselkedésnek (Andover \& Gibb, 2010). Az NSSI-cselekedetek minél részletesebb feltárása a jelenség mélyebb megértése szempontjából kiemelt jelentőséggel bír.

Az elmúlt évtizedekben több mérőeszközt is kifejlesztettek az NSSIviselkedés mérésére (ennek áttekintésére ld. Sansone és Sansone (2010) öszszefoglalóját). Ezek közül több csupán az önsértő viselkedés fajtáit, megjelenését és előfordulási gyakoriságát mérte fel (pl. Deliberate Self-Harm Inventory, DSHI; Gratz, 2001). Mások rendkívül hosszúak voltak (pl. SelfHarm Behavior Survey; Favazza, 1986) vagy az öngyilkosságra is rákérdeztek (pl. DSHI; Gratz, 2001).

A belga Laurence Claes és Walter Vandereycken azzal a hiánypótló céllal alakították ki önkitöltős NSSI-kérdőívüket, a Self-Injury QuestionnaireTreatment Related (SIQ-TR, magyarul: Kezelésközpontú Önsértés Kérdőív) elnevezésú méróeszközt (Claes \& Vandereycken, 2007b), hogy az egyes, nem öngyilkossági szándékkal történő önsértő viselkedésformák típusa és 
gyakorisága mellett több, az NSSI szempontjából fontos változót is felmérjenek: például az önsértő magatartás előtt és után megjelenő érzéseket, azok változását vagy az NSSI-cselekedet okát. Kérdőívüket a klinikai populációban megjelenő önsértés felmérésére dolgozták ki, kiemelt fontosságúnak tartva azoknak a külső és belső tényezőknek a feltárását, amelyek önsértő viselkedéshez vezetnek. A SIQ-TR a Vanderlinden és Vandereycken (1997) által kidolgozott Self-Injury Questionnaire (SIQ) továbbfejlesztett változata. A SIQ-ben ötféle önsértési mód (hajkitépés, karmolás, ütés, vágás és égetés) kapcsán kérdeztek rá gyakorisági adatokra, valamint a fájdalom mértékére és az önsértés során átélt érzelmekre. Kiegészítő információként rákérdeztek továbbá az önsértő viselkedés első megjelenésének idejére, a megsértett testfelület(ek)re, illetve arra, hogy az önsértő tett előre megtervezett volt-e vagy sem.

\subsection{A Kezelésközpontú Önsértés Kérdőív}

(Self-Injury Questionnaire-Treatment Related; SIQ-TR) felépítése

A mérőeszköz egymást követő egységekben ötféle önsértő viselkedésforma kapcsán kérdez rá számos, az önsértés pszichológiai ellátása során fontos tényezőre. Az ötféle önsértési mód a következő sorrendben követi egymást a kérdőívben: ha valaki szándékosan (1) megkarmolja, (2) megüti, (3) megvágja, (4) megégeti, (5) megharapja önmagát. A kitöltő a hatodik egységben egy olyan önsértési formát is megnevezhet, ami az előzóekben nem szerepelt, de a személy önsértési módként használja/használta. Ebben a hatodik részben is ugyanazon kérdések szerepelnek, mint az előző öt, előre megadott önsértési forma kapcsán, így az egyes önsértési módokra adott válaszok, jellegzetességek összehasonlíthatók. Amennyiben valaki többféle önsértési módot is használ(t), akkor mindegyik általa alkalmazott önsértő viselkedésre vonatkozóan kitölti a kérdőívet.

A kérdőív adott önsértő viselkedés esetében az (I) első, taxonomikus egységben arra kérdez rá, hogy az önsértő személy az adott viselkedést (1) mikor tette utoljára, (2) melyik testrészét/testrészeit sértette meg a legtöbbször, (3) az elmúlt hónapban hány napon történt ilyen, (4) egy nap alatt átlagosan hányszor fordult elő, (5) milyen gyakran (soha-tól a mindig-ig) és (6) mekkora mértékben (semennyire és nagyon erősen között) érzett közben fájdalmat. Minden kérdésnél előre adott válaszlehetőségek közül választhat a kitöltő.

Amennyiben az első kérdésre (Pl. „Mikor vágta meg magát szándékosan utoljára?") a személy azt válaszolja, hogy az adott önsértés egy hónappal ezelőtt történt, akkor a következő önsértési forma kérdéseire kell áttérnie. A kérdőívet adott önsértő viselkedés kapcsán tehát csak akkor kell ki- 
töltenie a válaszadónak, ha az önsértés egy hónapon belül történt. A mérőeszköz így csak az aktuális/közelmúltbeli önsértést méri fel részletességgel. Ugyanakkor egyéni felmérés, kezelés keretében - információszerzési céllal - a pszichológusnak arra is lehetősége van, hogy megkérje a pácienst, akkor is töltse ki az adott önsértési módra vonatkozó kérdéseket, ha ugyan azt az elmúlt egy hónapban nem, de valaha - akár egy alkalommal is alkalmazta. Ezzel a részletes kikérdezéssel a korábbi önsértő tettek pszichodinamikájáról - bár retrospektíve, de - számos információt nyerhet a kezelő.

A (II) második nagyobb egység négy attitüdinális kérdést tartalmaz az önsértő cselekedettel kapcsolatban: 4-fokú skálán (1 = soha és 4 = mindig) méri fel az eltervezettséget, a cselekvés tudatossági szintjét, a sebek ellátását, illetve az önsértés eltitkolását.

A (III) harmadik fő egység azokat az érzéseket méri fel az önsértés előtt és után, amelyeket a személy átélhetett. Itt 9-9 érzés szerepel: öröm, megkönnyebbülés, idegesség, unalom, harag önmagára, harag más irányába, szorongás, szomorúság, búntudat. Ezeket mind az önsértés előtti, mind az önsértés utáni állapotra vonatkoztatva megítéli a kitöltő. Amennyiben a 9 felsorolt érzésen kívül más érzelmi állapotot is átélt a személy, egy tizediket is megnevezhet, és értékelheti annak súlyosságát egy ötfokozatú skálán $(1=$ egyáltalán nem és $5=$ nagyon-nagyon). Az érzelmek négy skálát építenek fel: pozitív érzelmek az önsértés előtt; negatív érzelmek az önsértés előtt; pozitív érzelmek az önsértés után és negatív érzelmek az önsértés után.

Az utolsó (IV) nagy egység az adott önsértő viselkedés hátterében meghúzódó okokat kívánja feltárni (Miért csináltad mindezt? (Pl. „Miért szoktad megkarmolni/megcsikarni magadat?"). Ahogyan az érzések esetében, itt is ötfokú skálán jelölheti be valaki, hogy mennyire jellemző rá az adott ok, amikor önsértést követ el ( 1 = egyáltalán nem és $5=$ nagyon-nagyon). 14 okot (pl. „Hogy elkerüljem vagy elnyomjam a fájdalmas gondolatokat vagy emlékeket." vagy "Hogy figyelmet kapjak másoktól.") ítél meg a kitöltő aszerint, hogy az mekkora szerepet játszott az önsértő viselkedése során. Lehetősége van továbbá arra, hogy egy olyan okot is leírjon, ami az előzőekben nem szerepelt, de nála hangsúlyos az önsértő viselkedés végrehajtásakor. A lehetséges okok sorát, tehát az önsértés funkcióit Claes \& Vandereycken, (2007b) a korábbi szakirodalom (Brown, Comtoi, \& Linehan, 2002; Herpertz, 1995; Suyemoto, 1998; Vanderlinden \& Vandereycken, 1997) alapján állították össze. Ilyen funkció lehet például az önsértés önmegnyugtató, stimuláló, önbüntető, öndestruáló vagy éppen figyelemfelhívó szerepe.

Ennél a pontnál szükséges, hogy kitérjünk Nock és Prinstein $(2004,2005)$ rendszerezésére, amely az önsértő viselkedés négy elsődleges funkcióját írja le két dichotóm dimenzió mentén. Az önsértés lehet (1) ún. automatikus (azaz intraperszonális) vagy szociális (azaz interperszonális) célú, illetve 
(2) indulhat pozitív (valamilyen állapot elérése a cél) vagy negatív (valamilyen állapot elkerülése a cél) megerősítés miatt. Az automatikus-pozitív megerősítő funkció akkor áll fenn, amikor a személy azért végez önsértést, hogy valamilyen általa vágyott állapotot elérjen (pl. érezzen valamit, még akkor is, ha az fájdalom vagy pl. „Hogy némi örömöt érezzek.”). Automatikusnegatív funkció esetén a személy valamilyen negatív érzelmi állapotot szeretne elkerülni vagy csökkenteni az önsértés által (pl. „Hogy elkerüljem vagy elnyomjam a negatív érzéseket."). A szociális-pozitív megerősítés során az önsértést azért végzi valaki, hogy figyelmet szerezzen másoktól vagy valamit elérhessen a környezetétól (pl. „Hogy figyelmet kapjak másoktól.”). A szociálisnegatív funkció azokat az okokat foglalja össze, amelyekben az önsértő viselkedés azért történik, hogy a személy valamilyen társas feladat vagy interperszonális követelmény alól kibújhasson vagy elkerüljön valamilyen büntetést ( $\mathrm{pl}$. „Hogy elkerüljem azt, hogy valami olyan kellemetlen dolgot csináljak, amit nem akarok megtenni."). Claes és Vandereycken (2007b) elemzése szerint a SIQ-TR a Nock és Prinstein-féle felosztás négy funkciója közül hármat mér fel: az automatikus pozitív és az automatikus negatív megerősító funkciót, valamint a pozitív szociális megerősítő funkciót.

\subsection{Korábbi eredmények a mérőeszközzel - A SIQ-TR kérdőív pszichometriai jellemzői}

Claes és Vandereycken, $(2007 b)$ evészavarban szenvedő nők mintáján $\left(n_{\text {telies }}\right.$ minta $=273 ; n_{\text {aktuálisan önsértók }}=83$; utóbbiak átlagéletkora $=24,8$ év, $\mathrm{SD}=8,2$ év) vezették be a kérdóívet a kutatásba és a gyakorlatba, egyben tesztelték a méróeszköz megbízhatóságát és validitását is.

Az I. (az önsértés „demográfiai adatai”) és a II. nagy egység (attitúdök az önsértő viselkedéssel kapcsolatban) értékelése kérdésenként történik, ezért skálaképzésre itt nem nyílik lehetőség. Az ezekre a kérdésekre adott válaszokból képet kaphatunk az adott önsértő viselkedés megjelenésének idői, gyakorisági stb. adatairól. A III., azaz az önsértő tett előtt és után átélt érzelmek esetén fókomponens analízissel két-két nagyobb faktort azonosítottak: negatív érzések és pozitív érzések. A négy érzelmi skála belső megbízhatósága az alacsonytól (Negatív érzelmek önsértés előtt skála az idegesség item kivételével: Cronbach- $a=0,61$; Pozitív érzelmek önsértés után skála az unalom item kivételével: Cronbach- $a=0,51)$ a kiválóig terjed (Negatív érzelmek önsértés után skála az idegesség item kivételével: Cronbach- $a=0,90$; Pozitív érzelmek önsértés előtt skála az unalom item kivételével: Cronbach- $a=0,78)$. Az adott érzelem-skálákból az idegesség és az unalom tételek kivételére azért került sor, mert azok hiányában jelentósen javult a skálák belső megbízhatósága. Az elvártaknak megfelelően 
Claes és Vandereycken (2007b) vizsgálatában a Negatív érzelmek önsértés előtt skála pozitív irányú együttjárást mutatott az SCL-90 tünetbecslő kérdőív depresszió $(r=0,37)$ és ellenségesség $(r=0,26)$ alskáláival, míg a Negatív érzelmek önsértés után skála az SCL-90 szorongás és depresszió alskáláival korrelált pozitívan ( $r=0,28$ és 0,28$)$. A Pozitív érzelmek önsértés előtt és után skálák nem mutattak szignifikáns lineáris kapcsolatot a szorongásos, a depresszív és a hosztilitás értékekkel. A IV. nagy kérdőívegységet, az okokat firtató részt a szerzők feltáró faktorelemzéssel vizsgálták, ahol három faktort tudtak azonosítani. Az (1) automatikus-pozitív megerősítő funkció (6., 7., 8., 9. itemek), az (2) automatikus-negatív megerősítő funkció (2., 3., 4.) és a (3) pozitív szociális megerősítés (1., 5., 10., 11.) faktorok körvonalazódtak, amelyek együttesen a variancia $56 \%$-át fedték le. A három funkcionalitás faktor Cronbach-a mutatói éppen megfelelönek bizonyultak: 0,65-0,70 közötti értéket vettek fel.

A későbbi vizsgálatokban hasonlóan megbízható és valid mérőeszköznek találták a SIQ-TR-t. Claes és Muehlenkamp (2013) eredményei például holland anyanyelvú belga középiskolások mintáján az elvártaknak megfelelóen az önsértő cselekedetek és a negatív, illetve pozitív érzelmek következtében megjelenő impulzivitás kapcsolatát erősítették meg. Davey, Arcelus, Meyer és Bouman (2016) transznemúek és kontrollcsoport mintáiban is arra mutattak rá, hogy az aktuális önsértó viselkedés több pszichopatológiai tünettel, alacsonyabb önértékeléssel, testtel való elégedettséggel és társas támogatással kapcsolódik össze. Braga és Gonçalves (2014) eredményei egyetemisták körében erősítették meg az NSSI-cselekedetek és a mentális betegségtünetek pozitív irányú együttjárását.

\subsection{A jelen vizsgálat célkitúzései}

A hazai tesztbázisban tudomásunk szerint egyelőre nem szerepel olyan mérőeszköz, amely a nem szuicidális önsértésról komplex képet adna. A Kezelésközpontú Önsértés Kérdőív magyar változatának bevezetése ezt a hiányt pótolni képes, hiszen az önsértés gyakorisági adatain túl annak attitüdinális, emocionális és funkcionalitással kapcsolatos komponenseit is feltérképezi. A kérdőív megértése, kitöltése, valamint kiértékelése viszonylag egyszerú, továbbá mind a kutatók, mind a gyakorló szakemberek számára hasznos információkat nyújt.

Vizsgálatunk fó célja ezért a magyar nyelvú változat alkalmazhatóságának és pszichometriai jellemzóinek tesztelése. További célunk a felmért speciális - javítóintézeti - serdülő minta önsértéssel kapcsolatos adatainak közlése. Ehhez kapcsolódóan a mintán belül jelenleg önsértők, korábban önsértők és soha nem önsértők összehasonlítása is célunk volt a felmért 
pszichológiai konstruktumok - így a negatív életesemények, valamint az elkerülés-fókuszú érzelemregulációs mechanizmusok - mentén. Végül fontosnak tartottuk az önsértés korrelátumainak vizsgálatát is mintánkban. A szakirodalomban mind a megterheló életesemények (pl. Liu és mtsai, 2014), mind az érzelemszabályozás problémái (pl. Briere \& Gil, 1998; Nock, Prinstein, \& Sterba, 2009) az önsértés rizikófaktoraiként merülnek fel. Ugyanakkor a szakirodalmat áttekintve nincs tudomásunk arról, hogy ezen tényezőket együttesen vizsgálták volna, sem arról, hogy azt javítóintézeti közegben térképezték volna fel. Vizsgálatunk így feltáró jellegú e téren.

\section{Módszer}

\subsection{A SIQ-TR magyarra fordításának menete}

A SIQ-TR kérdőív részletes leírása az elméleti bevezető részét képezi. A SIQ-TR magyar változata mind szerkezetében, mind tartalmában megegyezik az eredeti változattal. Az eredeti, angol nyelvú mérőeszközt Laurence Claes engedélyével Reinhardt Melinda és Kökönyei Gyöngyi fordították magyarra 2017-ben. A fordítási folyamat visszafordítással is kiegészült, amelyet egy angol nyelvtanári végzettséggel is rendelkező klinikai szakpszichológus készített el. A visszafordított és az eredeti változatot Laurence Claes vetette össze. Tisztázó kérdései és megjegyzései nyomán a fordítók véglegesítették a magyar változatot. A magyar nyelvú kérdőívnek a Kezelésközpontú Önsértés Kérdőív elnevezést adtuk. A továbbiakban a magyar változat esetében - az egyszerúbb forma miatt - a SIQ-TR-HU rövidítést használjuk, ahol a „HU” a magyar kitételre utal. A kérdóív megtalálható a függelékben.

\subsection{Minta}

A mintát 244, javítóintézeti nevelésben lévő fiatal alkotta. A javítóintézetek célja a búnelkövetés szankcionálása mellett a búnelkövetéssel vádolt fiatalkorúak szocializációja és reszocializációja, elősegítve ezzel ezen fiatalok társadalmi és munkaerő-piaci integrációját (KSH, 2014). Egy egyéves időszak alatt Magyarország összes javítóintézetébe eljutottunk. A hazai öt javítóintézetból 226 fiú $(92,6 \%)$ és 18 lány $(7,4 \%)$ vállalkozott a kutatásban való részvételre. A KSH adatai szerint 2018-ban összesen 340 fő tartózkodott javítóintézetben az év folyamán (KSH, 2019). Annak oka, hogy közülük nem mindenkit tudtunk elérni többes: az adatfelvétel adott időpontokban zajlott, így egész évben nem voltunk jelen az intézményekben, másrészt voltak szökés- 
ben lévő vagy szigorított körülmények között őrzött fiatalok. A fiúk meghatározó jelenléte a mintában a javítóintézeti populáció specifikuma (DixonGordon, Harrison, \& Roesch, 2012; KSH, 2014). A minta nemi megoszlásának alapvető adottságait figyelembe véve az elemzésekból nem zártuk ki a lányokat. A lányokból álló részminta alacsony elemszáma miatt azonban a nemek közötti különbséget tesztelő próbastatisztikát nem végeztünk.

A teljes minta átlagéletkora 16,99 év $(S D=1,28$ év; terjedelem $=14-20$ év). A fiúk átlagéletkora 16,97 év (SD = 1,31 év; terjedelem = 14-20 év), míg a lányok átlagéletkora 17,28 év ( $S D=0,90$ év; terjedelem $=16-19$ év). A teljes minta 56,5\%-a $(n=138)$ jogerós ítélettel rendelkezik, 43,4\%-a $(n=106)$ pedig előzetes letartóztatásban van. A fiúk esetében: $57,1 \%$-uk $(n=129)$ kapta meg ítéletét, 42,9\%-uk még nem $(n=97)$. A lányoknál ez az arány: jogerős ítélete $50 \%$-nak van $(n=9)$, míg előzetes letartóztatásban szintén $50 \%$ van $(n=9)$. A fiúk $58 \%$-a $(n=131)$ bentléte alatt az általános iskolát, 28,8\%-a $(n=65)$ a középiskolát végzi, 13,2\%-uk $(n=30)$ már nem jár iskolába. A lányok $72,2 \%-a(n=13)$ jár a javítóintézetben általános iskolába, 27,8\%-uk $(n=5)$ középiskolába. A szülők legmagasabb iskolai végzettsége a fiúknál döntően általános iskola (anyák 38,1\%-a, apák 27,4\%-a) és középiskola (anyák 36,8\%-a, apák 42\%-a), csupán elenyésző arányban felsőfokú (anyák 5,8\%-a, apák 7,1\%-a). A lányok fele $(n=9)$ nem tudja édesanyja iskolai végzettségét, $27,8 \%$ pedig az apáét. A fennmaradó esetekben az anyák iskolai végzettsége jellemzóen szakmunkás $(22,2 \%)$ vagy általános iskola (16,7\%), ez hasonló az apák iskolai végzettségéhez (16,7\%-16,7\%-ban középiskola, szakmunkás és általános iskola, míg 11,1\%-11,1\%-ban az általános iskolát sem fejezték be vagy felsőfokú végzettséggel bírnak). A fiatalok közel egyötöde nem tudta megnevezni a szülei iskolai végzettségét. Ez részben annak a következménye, hogy számos javítóintézeti nevelt állami gondoskodásban nótt fel. A fiatalok $78,7 \%-\mathrm{a}(n=192)$ rendszeresen tartja a kapcsolatot családjával, 16,4\%-a $(n=40)$ pedig rendszertelenül, néhányan $(4,9 \%, n=12)$ viszont egyáltalán nem tartják a kapcsolatot a családjukkal.

\subsection{Mérőeszközök}

Serdülő Életesemény Kérdőív. Az eredetileg 70 itemet tartalmazó önkitöltő Serdülő Életesemény Kérdőív (SÉK) (Adolescent Life Event Questionnaire, ALEQ; Hankin \& Abramson, 2002) a jellemzően serdülőkorban előforduló negatív, markáns stresszforrást jelentó életeseményeket gyújti egybe, ami a kitöltő által tetszőlegesen bővíthetô az előre kialakított életesemény-listában nem szereplő, de a kitöltó által az elmúlt időben átélt negatív eseményekkel. A SÉK a negatív életeseményeket négy nagy csoportba osztja: (1) család és szülők (pl. „Egy közeli családtagod (szülő, testvér) nem tudott dolgozni sérülés 
vagy betegség miatt.”); (2) párkapcsolat ( $\mathrm{pl}$. „Megtudtad, hogy a barátod/barátnőd megcsalt.”); (3) iskola (pl. „Olyan osztályba kellett járnod, amit nem szerettél."), továbbá (4) barátok és társas tevékenységek (pl. „Vitád volt egy közeli barátoddal."). Benjamin L. Hankin, az életesemény-lista kialakítójának ajánlása szerint a felsorolt negatív életesemények egy lehetséges keretet adnak, amelyekből a kutatás célkitúzéséhez vagy a vizsgált minta speciális jellemzőihez igazodva választhatjuk ki a releváns itemeket, és nem szükséges minden esetben a teljes listát használnunk. A javítóintézeti közeghez igazodóan vizsgálatunkban az „iskola és osztály” életesemény-csoportot kivettük. Részben azért, mert ebben a mintában ezek a tételek kevéssé relevánsak, másrészt pedig azért, mert a populáció terhelhetőségét figyelembe véve egy minél rövidebb kérdéssort igyekeztünk kialakítani. A kérdőívben az az időintervallum is módosítható, amelyre visszagondolva a kitöltő megítéli, hogy adott életesemény megtörtént-e az életében. Jelen esetben az elmúlt hat hónap stresszel teli életeseményeire kérdeztünk rá. Az értékelés az eredeti amerikai kérdőívben egy ötfokozatú skálán történik a sohá-tól a mindig-ig. A magyar változat ettól eltér, mert több negatív életesemény (pl. „A szüleid elváltak.") kapcsán ez a skála nehezen értelmezhető, egyes esetekben (pl. „Egy közeli barátod meghalt.") pedig kifejezetten morbid konnotációkat von maga után. Emiatt a hazai változatban - Benjamin L. Hankinnel egyeztetve - a következő megoldást alakították ki a fordítók: minden életeseménynél a kitöltő elóször azt dönti el, hogy az adott negatív dolog megtörtént-e vele a jelzett időintervallumban. Amennyiben erre igen-nel válaszol, azt is értékelnie kell egy hatfokozatú skálán $(0=$ egyáltalán nem viselt meg és $5=$ nagyon súlyos hatás), hogy az adott negatív történés mekkora érzelmi hatással, megterheléssel járt a számára. A dichotomizált értékelést (megtörtént-e az adott negatív életesemény vagy sem) Hankin is alkalmazta saját vizsgálataiban (pl. Hankin, Stone, \& Wright, 2010). A kiértékelés során lehetőség van az összes életesemény, illetve az egyes kategóriákon (életterületeken) belüli életesemények összesítésére. A magasabb pontszám minden esetben fokozott stressznek való kitettséget jelent. Az ALEQ-t az eddig felhasznált munkákban kivétel nélkül kiváló reliabilitási és validitási adatokkal bíró mérőeszközként mutatják be (pl. Abela \& Hankin, 2011; Hankin \& Abramson, 2002; Hankin, Stone, \& Wright, 2010). A mérőeszközt bevezető tanulmányukban Hankin és Abramson (2002) 0,94-es Cronbach-a értéket dokumentáltak, míg a két hetet felölelő teszt-reteszt reliabilitás-érték 0,65 volt. Jelen vizsgálatban a teljes kérdőív megbízhatónak bizonyult (K-D $20=$ $0,84)^{1}$, három alskálája pedig eléri $\left(\mathrm{K}-\mathrm{D} 20_{\text {SÉKcsalád }}=0,72\right.$ és K-D $20_{\text {SÉKbarátok }}=$

\footnotetext{
1 A K-D 20 mutató a belső megbízhatóság mutatója dichotóm tételekből felépülő skálák esetében. Övezetei megegyeznek a Cronbach-a mutatóéval.
} 
0,74) vagy közelíti a megbízhatóság elfogadható értékét (K-D 20 $0_{\text {SÉKpárkapcsolat }}=$ 0,67). A magyar fordítás - Benjamin L. Hankin engedélyével, szabályos, többlépcsős fordítási folyamat alapján - Reinhardt Melinda és Szabó Judit munkája.

Kognitív Érzelem Reguláció Kérdôív-rövid változat. A 18 tételes Kognitív Érzelem-Reguláció Kérdőív rövid változata (short version of the Cognitive Emotion Regulation Questionnaire, CERQ-short; Garnefski \& Kraaij, 2006) is felvételre került vizsgálatunkban. A kérdőív azokat a kognitív folyamatokat térképezi fel, amelyeket a stresszes élethelyzetekben megjelenő érzelmek szabályozására alkalmazhatunk. A rövid CERQ megőrizte az eredeti kérdőív (Cognitive Emotion Regulation Questionnaire, CERQ; Garnefski, Kraaij, \& Spinhoven, 2001; magyar adaptációja Miklósi, Martos, KocsisBogár és Perczel Forintos [2011] munkája) 9 skáláját, azonban ebben az egyes skálákat már csak két-két tétel fedi le. Vizsgálatunkban a skálák közül több is gyenge belső megbízhatóságot mutatott (Cronbach- $a_{\text {elfogadás }}=0,70$; Cronbach- $a_{\text {pozitiv fókuszvaltás }}=0,59 ;$ Cronbach- $a_{\text {tervezés }}=0,69 ;$ Cronbach- $a_{\text {átértékelés }}=$ 0,55 ; Cronbach $-a_{\text {perspektivába helyezés }}=0,38$; Cronbach- $a_{\text {önvád }}=0,58$; Cronbach$a_{\text {rumináció }}=0,64$; Cronbach- $a_{\text {katasztrofizálás }}=0,72 ;$ Cronbach- $a_{\text {mások hibáztatása }}=0,43$ ). A több elfogadhatatlan Cronbach- $a$ érték azt jelzi, hogy a kérdóív számos alskálája a vizsgált mintában nem méri megbízhatóan az adott érzelemszabályozási mechanizmust. Ennek háttere részben a skálákat felépító alacsony tételszám lehet, másrészt a felmért populációban nagyobb arányban előforduló szövegértési nehézségek, illetve az érzelmi folyamatokra irányuló reflexió problémái. A fentiek miatt a kérdőív eredményeit nem vontuk be az elemzéseinkbe.

A Tapasztalati Elkerülés Kérdőív (Avoidance and Fusion Questionnaire for Youth, AFQ-Y8; Greco, Lambert, \& Baer, 2008) egy nyolc tételből álló skála, amely a pszichés rugalmatlanság markereit, így a tapasztalatok (pl. érzelmek, emlékek, gondolatok) elkerülésére irányuló tendenciákat méri fel. A tapasztalati elkerülés jelentős kognitív rugalmatlanságot jelez, így az AFQ-Y8 a kognitív inflexibilitás mutatója is (Greco és mtsai, 2008). A tételeket egy ötfokú skálán kell a kitöltónek magára vonatkoztatva megítélni $(0=$ egyáltalán nem igaz és $4=$ nagyon igaz). Renshaw (2016) mérései szerint a kérdôíven elért minimum 15 pont klinikai szintú internalizáló tünetek jelenlétét jelzi. A vizsgálatok eredményei alapján a kérdőív egyfaktoros struktúrába szerveződik, az összpontszám pedig pozitív irányú együttjárást mutat a testi és mentális betegségtünetekkel, valamint a viselkedési problémákkal (pl. Greco és mtsai, 2008; Szemenyei és mtsai, 2018). A belső megbízhatóság mutatói megfelelőek (pl. Cronbach- $a=0,83$ [Greco és mtsai, 2008], vagy Cronbach- $a=0,74$ [Szemenyei és mtsai, 2018]). Vizsgálatunk is hasonló eredményt mutatott fel (Cronbach- $a=0,75)$. A magyar adaptációt Szemenyei Eszter és munkatársai (Szemenyei és mtsai, 2018) készítették el. 
Serdülő Disszociatív Tapasztalatok Skála. A kifejezetten serdülőkre kialakított disszociatív élményeket felmérô skála (Adolescent Dissociative Experience Scale, A-DES; Armstrong, Putnam, Carlson, Libero, \& Smith, 1997) 30 tételból áll. A válaszokat a kitöltő egy 11-fokozatú skálán adja meg a 0 = soha és a $10=$ mindig végpontok között. Minél magasabb az összpontszám, annál markánsabb disszociatív tapasztalatokról számol be a kitöltő. Kisiel és Lyons (2001) a 4 pont vagy az afeletti skálaátlagot (a teljes skála összpontszáma osztva a tételek számával) határozták meg, mint a patológiás mértékú disszociáció jelzőszámát. A mérőeszközt bevezető tanulmány négy alskálát is felsorol, amelyek a disszociáció alapvető aspektusait ragadják meg: (1) disszociatív amnézia, (2) abszorpció és képzeleti bevonódás, (3) passzív elszenvedés, (4) deperszonalizáció és derealizáció (Armstrong és mtsai, 1997). Mind a teljes skála, mind az alskálák belsó megbízhatósága kiváló vagy jó: az eredeti tanulmányban a Cronbach-a értékek 0,72 és 0,93 között mozogtak (Armstrong és mtsai, 1997). Jelen tanulmányban a teljes skála reliabilitása kiváló volt (Cronbach- $a=0,94)$, ahogyan az egyes alskálák is megbízhatónak bizonyultak (Cronbach- $a_{\text {disszociatív amnézia }}=0,79$; Cronbach- $a_{\text {abszorpció }}=0,73$; Cronbach- $a_{\text {passziv elszenvedés }}=0,75$; Cronbach- $a_{\text {derealizáció }}$ $=0,85)$. A négy alskálát későbbi kutatások nem tudták egyértelmúen reprodukálni, az egyfaktoros változat mutatta a legjobb illeszkedést (pl. Farrington, Waller, Smerden, \& Faupel, 2001; Muris, Merckelbach, \& Peeters, 2003). A magyar változat Magi Anna munkája, adaptálása folyamatban van.

\subsection{Eljárás és etikai vonatkozások}

A kutatás megtervezése és lefolytatása minden tekintetben a Helsinki Nyilatkozat (WHO, 2001) etikai alapelveivel összhangban történt. A vizsgálatra az Eötvös Loránd Tudományegyetem Pedagógiai és Pszichológiai Kar Kutatásetikai Bizottsága adott ki kutatásetikai engedélyt 2017/60. számmal 2017. március 1-jén. A kérdőíveket csak azok a neveltek töltötték ki, akik a részvételre önként vállalkoztak és előzetes informált beleegyezésüket adták ahhoz. A részvétel névtelenül zajlott, a kamaszok által aláírt beleegyezó nyilatkozatok semmiféle módon nem voltak összepárosíthatóak a névtelenül kitöltött kérdőívekkel. A javítóintézetek vezetői előzetesen írásos engedélyüket adták a kutatás lefolytatásához.

A javítóintézeti szabályrendszer miatt a fiatalok a kérdőíveket tableten töltötték ki offline módban, azaz a kitöltés alatt az internethez nem férhettek hozzá, ugyanakkor a táblagépen való kitöltéstől a részvételi motiváció fokozódását vártuk. Az offline kérdőívek kezelésével a tapasztalatok szerint a nevelteknek nem volt gondjuk. A fogvatartott kamaszok jellemzően 3-5 
fős csoportokban egy csendes szobában, egymástól elszeparáltan töltötték ki a tesztanyagot képzett kutatásvezetők felügyeletével. A javítóintézetekből a kitöltés alatt személyzet nem volt jelen és az anonim kitöltésekbe sem tekinthettek bele. A vizsgálatra való felkérést senki sem utasította vissza, azonban több (funkcionális) analfabéta fogvatartott is volt, illetve néhányan szigorított őrizetben voltak a tesztfelvétel ideje alatt vagy szökésben voltak, így nem állt módjukban részt venni a felmérésben. Több olyan eset is elófordult, hogy az adott fiatal írás-olvasási nehézségei ellenére is szeretett volna bekapcsolódni a vizsgálatba. Az ilyen esetekben egyesével, négyszemközti helyzetben a kutatásvezető felolvasta a kérdőív tételeit és a fiatal válaszát rögzítette a tableten. A kérdőívek kitöltését követóen a kamaszoknak igény szerint lehetőségük nyílt a kutatásvezetőkkel informálisan beszélgetni, az esetleges negatív érzéseiket, amelyek a kérdőív kitöltése közben jelentkeztek, ezzel levezetni. Továbbá mind a vizsgálat előtt, mind azután felhívtuk a kitöltők figyelmét, amennyiben szükségét érzik, problémáikkal felkereshetik az intézmény pszichológusainak valamelyikét.

\subsection{Statisztikai elemzés}

A minta leíró jellemzóinek megadásához átlagokat, szórásokat, valamint gyakorisági adatokat közöltünk. A SIQ-TR-HU kérdőív egyes nagyobb taxonomikus egységeinek (az önsértés leíró és attitüdinális jellemzői, kapcsolódó érzelmek és okok) mintánkra vonatkozó eredményeit gyakorisági adatokkal és átlagértékekkel mutattuk be. Az önsértés előtt és azt követően átélt érzelmi állapotokban történő változást összetartozó mintás $t$-próbával teszteltük. Az aktuálisan önsértők, a korábban önsértők és a sohasem önsértők összehasonlítása a felmért változók mentén egyszempontos varianciaanalízissel (ANOVA) történt. A csoportok páronkénti összehasonlítására Tukey-féle utóelemzést alkalmaztunk. A hatásméretet az összetartozó mintás $t$-próba esetében Cohen- $d$ mutatóval, ANOVA esetében $\eta 2$-tel, míg ismételt mérési elrendezésnél $d_{\mathrm{RM}}$ mutatóval számítottuk. A vizsgálatba bevont változók összefüggéseit Pearson-féle korrelációs elemzéssel, Bonferroni-korrekcióval kiegészítve vizsgáltuk. Az alkalmazott kérdőívek skáláinak belső megbízhatóságát ordinális tételek esetében Cronbach-alfa, dichotóm tételek esetében pedig K-D 20 mutató számításával becsültük meg. A szignifikanciaszintet általánosságban 95\%-os megbízhatósági szinten határoztuk meg, korrelációs elemzések esetében pedig Bonferronikorrekció alapján. Az elemzéseket az SPSS 25.0 statisztikai programcsomaggal hajtottuk végre. 


\section{Eredmények}

\subsection{Az önsértő viselkedés leíró jellemzői a mintában}

A teljes minta 26,2\%-ánál $(n=64)$ aktuálisan is jelen van az önsértés valamely formája, azaz ez a csoport az elmúlt egy hónapban végzett valamilyen önsértést. 34,4\% $(n=84)$ ennél korábban jelzett az élete során önsértó cselekedetet. 39,3\% $(n=96)$ pedig saját bevallása szerint sohasem volt önsértő. A jelenleg önsértő fiatalok többsége egyféle önsértési módot használ, de a teljes minta 10,7\%-a aktuálisan is többféle módon sérti magát. A jelenleg önsértók közül 59,4\% ( $n=38)$ egyféle, 29,7\% $(n=19)$ kétféle, 3,1\% $(n=2)$ háromféle, 6,3\% $(n=4)$ négyféle, míg 1,6\% $(n=1)$ ötféle módon önsérti magát. A jelenleg önsértők nagyobb része (53,1\%-a, $n=34)$ az elmúlt 30 napból 1-5 nap során végzett önsértést. A leggyakoribb önsértési forma az ütés (önmaga megütése, testrészek beütése pl. falba). Az ütést a karmolás és a vágás követi, majd a harapás. Az égetés a legritkább önsértési forma, amely csak a fiúknál fordult elő. A leggyakrabban megsértett testrészek a karok és a kezek, illetve a fej és a nyak területe. A három leggyakoribb önsértési forma (ütés, karmolás, vágás) közben átélt szubjektív fájdalomélmény leginkább a fájdalom hiánya vagy annak enyhe, illetve közepes mértéke. A fájdalomélmény átlaga ütés esetén $2,04(\mathrm{SD}=0,98$; terjedelem $=1-4)$, karmolás során $2,32(\mathrm{SD}=1,31$; terjedelem $=1-5)$, és a vágáshoz kapcsolódóan 2,27 (SD = 1,37 ; terjedelem $=1-5$ ) volt. A teljes mintára vonatkozó gyakorisági adatokat - tájékoztató jelleggel nemi bontással is kiegészítve - az 1. táblázat tartalmazza.

1. táblázat. A javítóintézeti mintára jellemző önsértési adatok

\begin{tabular}{|c|c|c|c|c|}
\hline \multicolumn{2}{|c|}{ Változó } & \multirow{2}{*}{$\begin{array}{c}\text { Teljes minta } \\
\left(\begin{array}{c}(n=244) \\
\%(n)\end{array}\right. \\
26,2(64)\end{array}$} & \multirow{2}{*}{$\begin{array}{c}\text { Fiú } \\
(n=226) \\
\%(n) \\
23,5(53)\end{array}$} & \multirow{2}{*}{$\begin{array}{c}\begin{array}{c}\text { Lány } \\
(n=18) \\
\%(n)\end{array} \\
61,1(11)\end{array}$} \\
\hline Önsértő-e & aktuálisan & & & \\
\hline & korábban & $34,4(84)$ & $34,5(78)$ & $33,3(6)$ \\
\hline & sohasem & $39,3(96)$ & $42,0(95)$ & $5,6(1)$ \\
\hline \multirow{2}{*}{$\begin{array}{l}\text { Jelenleg önsértő hány } \\
\text { önsértési módot használ }\end{array}$} & egyféle & $15,6(38)$ & $14,2(32)$ & $33,3(6)$ \\
\hline & többféle & $10,7(26)$ & $9,3(21)$ & $27,8(5)$ \\
\hline \multirow{3}{*}{$\begin{array}{l}\text { Önsértés gyakorisága } \\
\text { az elmúlt hónapban }\end{array}$} & 1-5 nap között & $13,9(34)$ & $12,8(29)$ & $27,8(5)$ \\
\hline & 6-15 nap között & $6,6(16)$ & $6,2(14)$ & $11,1(2)$ \\
\hline & $>15$ nap & $5,7(14)$ & $4,4(10)$ & $22,2(4)$ \\
\hline
\end{tabular}




\section{1. táblázat folytatása}

\begin{tabular}{|c|c|c|c|c|}
\hline \multicolumn{2}{|c|}{ Változó } & \multirow{2}{*}{$\begin{array}{c}\text { Teljes minta } \\
(n=244) \\
\%(n)\end{array}$} & \multirow{2}{*}{$\begin{array}{c}\text { Fiú } \\
(n=226) \\
\%(n) \\
9,3(21)\end{array}$} & \multirow{2}{*}{$\begin{array}{c}\begin{array}{c}\text { Lány } \\
(n=18) \\
\%(n)\end{array} \\
22,2(4)\end{array}$} \\
\hline Önsértési módok típusa & karmolás & & & \\
\hline & ütés & $15,2(37)$ & $13,7(31)$ & $33,3(6)$ \\
\hline & vágás & $10,7(26)$ & $9,3(21)$ & $27,8(5)$ \\
\hline & égetés & $1,6(4)$ & $1,8(4)$ & $0(0)$ \\
\hline & harapás & $4,5(11)$ & $4,4(10)$ & $5,6(1)$ \\
\hline \multirow{5}{*}{$\begin{array}{l}\text { Leggyakrabban } \\
\text { megsértett testrész } \\
\text { karmolás esetén }\end{array}$} & fej, nyak & $2,9(7)$ & $3,1(7)$ & $0(0)$ \\
\hline & karok, kezek & $7,0(17)$ & $5,8(13)$ & $22,2(4)$ \\
\hline & törzs, has & $0,4(1)$ & (0) & $5,6(1)$ \\
\hline & lábak & $2,0(5)$ & $0,9(2)$ & $16,7(3)$ \\
\hline & nemi szervek & $0,8(2)$ & $0,4(1)$ & $5,6(1)$ \\
\hline \multirow{5}{*}{$\begin{array}{l}\text { Leggyakrabban } \\
\text { megsértett testrész } \\
\text { ütés esetén }\end{array}$} & fej, nyak & $9,0(22)$ & $8,0(18)$ & $22,2(4)$ \\
\hline & karok, kezek & $8,2(20)$ & $7,1(16)$ & $22,2(4)$ \\
\hline & törzs, has & $0,4(1)$ & $0,4(1)$ & $0(0)$ \\
\hline & lábak & $1,2(3)$ & $1,3(3)$ & $0(0)$ \\
\hline & nemi szervek & $0,8(2)$ & $0,9(2)$ & $0(0)$ \\
\hline \multirow{5}{*}{$\begin{array}{l}\text { Leggyakrabban } \\
\text { megsértett testrész } \\
\text { vágás esetén }\end{array}$} & fej, nyak & $2,0(5)$ & $1,8(4)$ & $5,6(1)$ \\
\hline & karok, kezek & $7,8(19)$ & $6,2(14)$ & $27,8(5)$ \\
\hline & törzs, has & $0(0)$ & $0(0)$ & $0(0)$ \\
\hline & lábak & $0,8(2)$ & $0,4(1)$ & $5,6(1)$ \\
\hline & nemi szervek & $0,4(1)$ & $0,4(1)$ & $0(0)$ \\
\hline \multirow{5}{*}{$\begin{array}{l}\text { Fájdalom mértéke } \\
\text { karmolás közben }\end{array}$} & semennyire & $3,7(9)$ & $3,1(7)$ & $11,1(2)$ \\
\hline & enyhén & $3,3(8)$ & $3,1(7)$ & $5,6(1)$ \\
\hline & közepesen & $2,5(6)$ & $2,2(5)$ & $5,6(1)$ \\
\hline & erősen & $0,8(2)$ & $0,9(2)$ & $0(0)$ \\
\hline & nagyon erósen & $0(0)$ & $0(0)$ & $0(0)$ \\
\hline \multirow{5}{*}{$\begin{array}{l}\text { Fájdalom mértéke } \\
\text { ütés közben }\end{array}$} & semennyire & $5,3(13)$ & $3,5(8)$ & $27,8(5)$ \\
\hline & enyhén & $3,7(9)$ & $4,0(9)$ & $0(0)$ \\
\hline & közepesen & $3,7(9)$ & $3,5(8)$ & $5,6(1)$ \\
\hline & erősen & $0,8(2)$ & $0,9(2)$ & $0(0)$ \\
\hline & \begin{tabular}{|l|} 
nagyon erősen \\
\end{tabular} & $1,6(4)$ & $1,8(4)$ & $0(0)$ \\
\hline
\end{tabular}


1. táblázat folytatása

\begin{tabular}{|c|c|c|c|c|}
\hline \multicolumn{2}{|c|}{ Változó } & \multirow{2}{*}{$\begin{array}{c}\text { Teljes minta } \\
\left(\begin{array}{c}n=244) \\
\%(n)\end{array}\right. \\
4,5(11)\end{array}$} & \multirow{2}{*}{$\begin{array}{c}\begin{array}{c}\text { Fiú } \\
(n=226) \\
\%(n)\end{array} \\
3,5(8)\end{array}$} & \multirow{2}{*}{$\begin{array}{c}\begin{array}{c}\text { Lány } \\
(n=18) \\
\%(n)\end{array} \\
16,7(3)\end{array}$} \\
\hline Fájdalom mértéke vágás & semennyire & & & \\
\hline & enyhén & $2,0(5)$ & $2,2(5)$ & $0(0)$ \\
\hline & közepesen & $1,6(4)$ & $1,3(3)$ & $5,6(1)$ \\
\hline & erősen & $1,6(4)$ & $1,3(3)$ & $5,6(1)$ \\
\hline & nagyon erősen & $0,8(2)$ & $0,9(2)$ & $0(0)$ \\
\hline
\end{tabular}

\subsection{Az önsértés attitüdinális komponensei}

Az önsértéssel kapcsolatos attitúdöket az ötféle önsértési mód esetében külön-külön vizsgáltuk (2. táblázat). A teljes aktuálisan önsértő minta $(n=64)$ átlagértékeit a válasz-skálához viszonyítva a tervezettség tekintetében a karmolás és a vágás ritkábban eltervezettnek számít, míg az ütés, a harapás és az égetés még kevésbé tervezett cselekedet, az átlagértékek ezekben az esetekben a "soha” válasz értékéhez (1) közelítenek. Az önsértó tettre való tudatos reflexió a karmolás és az ütés esetében fokozottabb, átlagosan gyakran jelenik meg, míg az égetés esetében ez a tudatosság alacsony mértékú. Az önsértés során szerzett sebek ellátása a karmolás esetében a legkifejezettebb, az égetést és a harapást követően a sebekről való gondoskodás jellemzóen ritkább. Ezek az értékek tendenciájukban hasonlóak Claes és Vandereycken (2007b) mérőeszközt bevezető kutatásához, amelyben 83 evészavarral küzdő, aktuálisan önsértő nő szerepelt. Az önsértés mások előli elrejtésére, eltitkolására való hajlandóság mind az öt önsértési mód esetében alacsony mintánkban, szemben Claes és Vandereycken (2007b) női evészavaros mintájával, ahol az önsértés titokban tartására való törekvés átlagosan "gyakorta" fordult elö. 
2. táblázat. Az önsértési módokhoz kapcsolódó attitúdök leíró statisztikai adatai az aktuálisan önsértők mintájában

\begin{tabular}{|c|c|c|c|c|c|}
\hline Attitúd* & $\begin{array}{c}\text { Karmolás } \\
(n=25) \\
\text { M (SD) } \\
\text { [terjedelem] }\end{array}$ & $\begin{array}{c}\text { Ütés } \\
(n=37) \\
\mathbf{M} \text { (SD) } \\
\text { [terjedelem] }\end{array}$ & $\begin{array}{c}\text { Vágás } \\
(n=26) \\
\text { M (SD) } \\
\text { [terjedelem] }\end{array}$ & $\begin{array}{c}\text { Égetés } \\
(n=4) \\
\mathbf{M}(\mathrm{SD}) \\
\text { [terjedelem] }\end{array}$ & $\begin{array}{c}\text { Harapás } \\
(n=11) \\
\text { M (SD) } \\
\text { [terjedelem] }\end{array}$ \\
\hline Tervezettség & $\begin{array}{c}2,04(1,17) \\
{[1-4]}\end{array}$ & $\begin{array}{c}1,62(1,04) \\
{[1-4]}\end{array}$ & $\begin{array}{c}2,00(1,23) \\
{[1-4]}\end{array}$ & $\begin{array}{c}1,25(0,50) \\
{[1-2]}\end{array}$ & $\begin{array}{c}1,55(1,04) \\
{[1-4]}\end{array}$ \\
\hline $\begin{array}{l}\text { Tudatos } \\
\text { rálátás }\end{array}$ & $\begin{array}{c}2,80(1,00) \\
{[1-4]}\end{array}$ & $\begin{array}{c}2,78(1,18) \\
{[1-4]}\end{array}$ & $\begin{array}{c}2,31(1,19) \\
{[1-4]}\end{array}$ & $\begin{array}{c}1,50(0,58) \\
{[1-2]}\end{array}$ & $\begin{array}{c}2,27(1,10) \\
{[1-4]}\end{array}$ \\
\hline $\begin{array}{l}\text { Sebek } \\
\text { ellátása }\end{array}$ & $\begin{array}{c}2,64(1,22) \\
{[1-4]}\end{array}$ & $\begin{array}{c}2,35(1,29) \\
{[1-4]}\end{array}$ & $\begin{array}{c}2,27(1,31) \\
{[1-4]}\end{array}$ & $\begin{array}{c}2,00(1,41) \\
{[1-4]}\end{array}$ & $\begin{array}{c}2,00(1,27) \\
{[1-4]}\end{array}$ \\
\hline $\begin{array}{l}\text { Tett } \\
\text { eltitkolása }\end{array}$ & $\begin{array}{c}1,92(1,01) \\
{[1-4]}\end{array}$ & $\begin{array}{c}2,27(1,17) \\
{[1-4]}\end{array}$ & $\begin{array}{c}2,23(1,37) \\
{[1-4]}\end{array}$ & $\begin{array}{c}1,25(0,50) \\
{[1-2]}\end{array}$ & $\begin{array}{c}2,27(1,27) \\
{[1-4]}\end{array}$ \\
\hline
\end{tabular}

Megjegyzés: *4-fokú skálán értékelve ( 1 = soha és 4 = mindig). M = átlag, SD = szórás.

\subsection{Az önsértést megelőző és követő érzelmek jellemzői}

Az aktuálisan önsértők körében az öt önsértési módra külön-külön lebontva közöljük a Claes és Vandereycken (2007b) által meghatározott önsértés előtti és utáni érzelmek átlag és szórásértékeit (3. táblázat). Claes és Vandereycken (2007b) fókomponens analízissel négy érzelmi faktort azonosítottak: negatív érzések önsértés előtt és azt követően, valamint pozitív érzések az önsértő tett előtt és után (részletesen ld. 1.2. fejezet). Átlagosan a legkevesebb negatív érzelem - mind az önsértés előtt, mind azt követően - az égetés módszerénél jelenik meg, míg a legtöbb negatív emóció a karmolás és az ütés előtt és után jelentkezik. Szintén az égetés előtt és után indukálódik a legkevesebb pozitív érzelem. Megbízhatóságot csak azokban az esetekben számoltunk, ahol adott csoport mintaelemszáma elérte a 25 fót, így a karmolás, az ütés és a vágás esetén. Vizsgálatunkban a Negatív érzelmek önsértés előtt és Negatív érzelmek önsértés után skálák a három önsértési mód esetében kiváló belső konzisztenciával rendelkeznek. A Pozitív érzelmek önsértés előtt és a Pozitív érzelmek önsértés után skálák az ütés és a vágás esetén nem mindenkor érik el a megbízhatóság minimumértékét, míg a karmolás esetében megbízhatónak bizonyulnak. Az önsértést követően megítélt pozitív érzelmek összesített skálájának (az öt önsértési módot egybevonták) belső megbízhatósága Claes és Vandereycken (2007b) vizsgálatában hasonlóképpen rossz reliabilitással bírt (Cronbach- $a=0,50)$. 


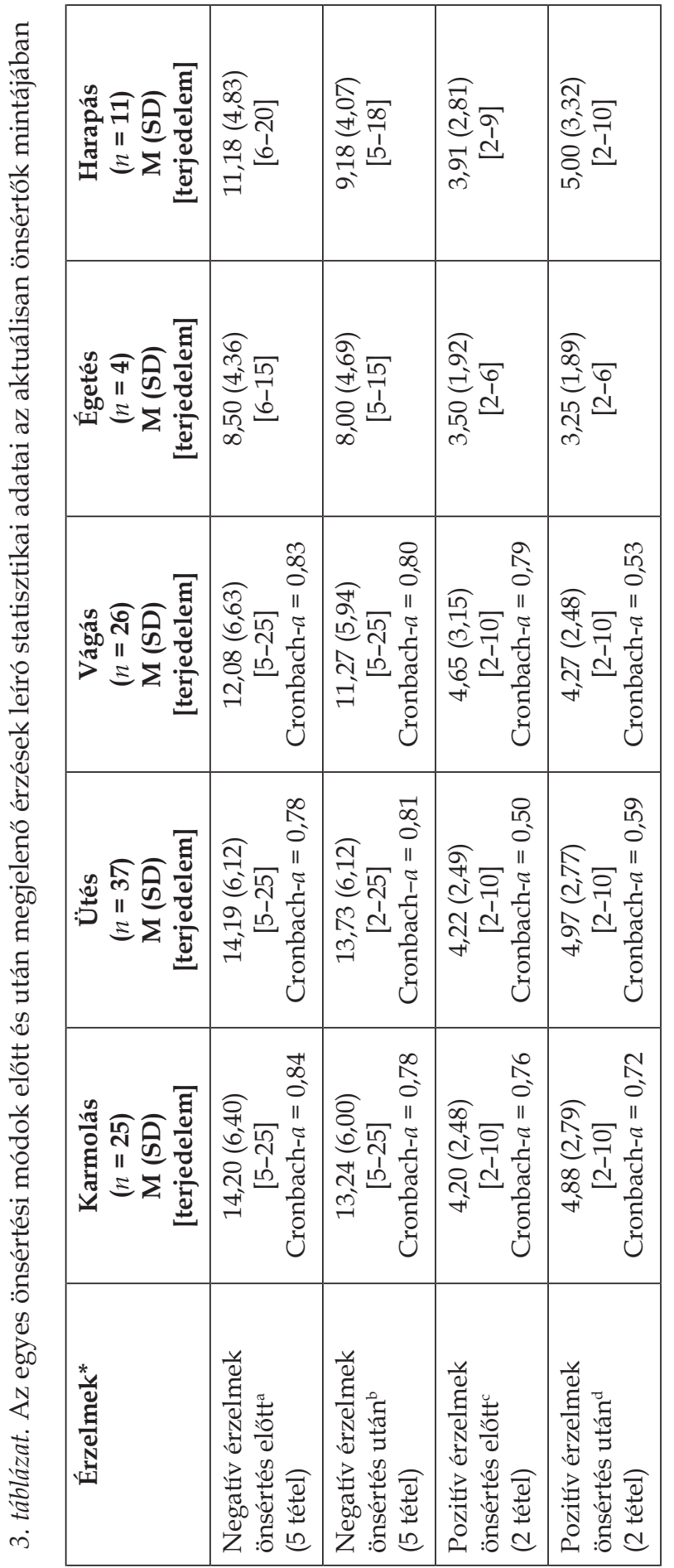

总离离离 ํ.

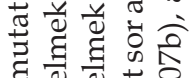

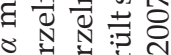
ป⿱艹乂

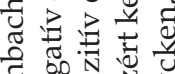

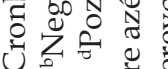
षें 嵅

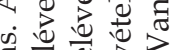

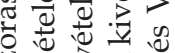

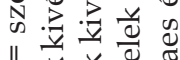
II क

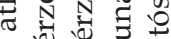
II $\infty$ ฐ స $\Sigma D_{0}^{\infty} 00$ $\therefore \underbrace{}_{0} \cong 0$ के इ

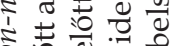

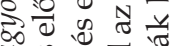

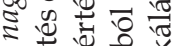
II เก

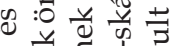
ป $\sim \mathcal{N}$ 足

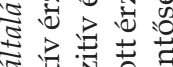

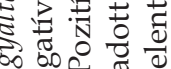
8000 T.

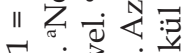

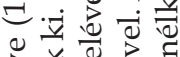
光造它

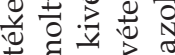

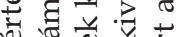
ส ब है छ : w

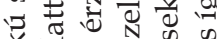
눙 พั is N

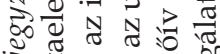

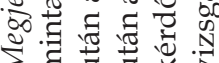


Az önsértéssel asszociálódó érzelmi állapotok kapcsán önsértési módonként megvizsgáltuk azt is, hogy az adott önsértési típus megjelenése előtt és után - retrospektíven visszatekintve - megélt pozitív, illetve negatív érzelmek átlagában van-e szignifikáns különbség (4. táblázat). Az elemzéseket a karmolás, az ütés és a vágás esetében csak akkor végeztük el, amennyiben az egyes érzelmi skálák megfelelő reliabilitás-értékkel bírtak. Eredményeink szerint egyik esetben sem mutatkozik szignifikáns eltérés az önsértés előtt és után átélt pozitív, illetve negatív érzelmek intenzitásában. Megjegyezzük azonban, hogy a harapás esetében mind a pozitív, mind a negatív érzelmi állapotokban tendenciaszintú változás körvonalazódik: harapást követően a pozitív érzelmek növekedése és a negatív érzelmek csökkenése feltételezhető, ami magasabb elemszám esetén szignifikáns különbséget is elérhet. Mind a pozitív, mind a negatív érzelmek esetében - önsértési módonként - ellenőriztük az önsértés előtti és utáni érzelmi állapotok közötti együttjárást is. A két változó (önsértést megelőző és követő érzelmek) értékei - egy kivétellel - erősen korrelálnak, ami azok nagymértékú együttmozgását jelzi. A karmolást megelőző és azt követő pozitív érzelmek korrelációja mutat csupán tendenciaszintú közepes mértékú együttjárást. Összességében mindez a vizsgált érzelmi faktorok megfelelő reliabilitását támasztja alá.

4. táblázat. Az egyes önsértési módok előtt és után átélt pozitív, illetve negatív érzelmek összetartozó mintás elemzése

\begin{tabular}{|c|c|c|c|c|}
\hline $\begin{array}{c}\text { Az önsértés } \\
\text { típusa }\end{array}$ & $\begin{array}{l}\text { Pozitív érzelmek } \\
\text { elótte } \\
\text { M (SD) }\end{array}$ & $\begin{array}{c}\text { Pozitív érzelmek } \\
\text { utána } \\
\text { M (SD) }\end{array}$ & $t(\mathrm{DF}) ; p ; d_{\mathrm{RM}}$ & $r^{*} ; p$ \\
\hline $\begin{array}{l}\text { karmolás } \\
(n=25)\end{array}$ & $4,20(2,48)$ & $4,88(2,79)$ & $\begin{array}{c}t(24)=-1,15 \\
p=0,26 \\
\mathrm{~d}_{\mathrm{RM}}=0,25\end{array}$ & $\begin{aligned} r & =0,38 ; \\
p & =0,063\end{aligned}$ \\
\hline $\begin{array}{l}\text { égetés } \\
(n=4)^{* *}\end{array}$ & $3,50(1,92)$ & $3,25(1,89)$ & $\begin{array}{c}t(3)=1,00 \\
p=0,39 ; \\
\mathrm{d}_{\mathrm{RM}}=0,53\end{array}$ & $\begin{aligned} r & =0,97 ; \\
p & =0,034\end{aligned}$ \\
\hline $\begin{array}{l}\text { harapás } \\
(n=11)\end{array}$ & $3,91(2,81)$ & $5,00(3,32)$ & $\begin{array}{c}t(10)=-1,88 \\
p=0,09 \\
\mathrm{~d}_{\mathrm{RM}}=0,65\end{array}$ & $\begin{aligned} r & =0,82 ; \\
p & =0,002\end{aligned}$ \\
\hline
\end{tabular}


4. táblázat folytatása

\begin{tabular}{|l|c|c|c|c|}
\hline $\begin{array}{c}\text { Az önsértés } \\
\text { típusa }\end{array}$ & $\begin{array}{c}\text { Negatív érzelmek } \\
\text { elótte M (SD) }\end{array}$ & $\begin{array}{c}\text { Negatív érzelmek } \\
\text { utána } \\
\text { M (SD) }\end{array}$ & $\boldsymbol{t}(\mathbf{D F}) ; \boldsymbol{p} ; \boldsymbol{d}_{\mathrm{RM}}$ & $\boldsymbol{r} ; \boldsymbol{p}$ \\
\hline $\begin{array}{l}\text { karmolás } \\
(n=25)\end{array}$ & $14,20(6,40)$ & $13,24(6,00)$ & $\begin{array}{c}t(24)=1,31 ; \\
\mathrm{p}=0,20 ; \\
\mathrm{d}_{\mathrm{RM}}=0,26\end{array}$ & $\begin{array}{c}r=0,83 ; \\
p<0,0001\end{array}$ \\
\hline $\begin{array}{l}\text { ütés } \\
(n=37)\end{array}$ & $14,19(6,12)$ & $13,73(6,12)$ & $\begin{array}{c}t(36)=0,70 ; \\
\mathrm{p}=0,49 ; \\
\mathrm{d}_{\mathrm{RM}}=0,12\end{array}$ & $\begin{array}{c}r=0,79 ; \\
\mathrm{p}<0,0001\end{array}$ \\
\hline $\begin{array}{l}\text { vágás } \\
(n=26)\end{array}$ & $12,08(6,63)$ & $11,52(5,92)$ & $\begin{array}{c}t(24)=0,77 ; \\
\mathrm{p}=0,48 ; \\
\mathrm{d}_{\mathrm{RM}}=0,15\end{array}$ & $\begin{array}{c}r=0,84 ; \\
\mathrm{p}<0,0001\end{array}$ \\
\hline $\begin{array}{l}\text { égetés } \\
(n=4)^{* *}\end{array}$ & $8,50(4,36)$ & $8,00(4,69)$ & $\begin{array}{c}t(3)=1,73 ; \\
\mathrm{p}=0,18 ;\end{array}$ & $\begin{array}{c}r=0,72 ; \\
\mathrm{p}<0,013\end{array}$ \\
\hline $\begin{array}{l}\mathrm{d}_{\mathrm{RM}}=0,15 \\
(n=11)\end{array}$ & $11,18(4,83)$ & $9,18(4,07)$ & $\begin{array}{c}t(10)=1,93 ; \\
\mathrm{p}=0,08 ; \\
\mathrm{d}_{\mathrm{RM}}=2,93\end{array}$ & $\begin{array}{c}r=0,99 ; \\
\mathrm{p}<0,005\end{array}$ \\
\hline
\end{tabular}

Megjegyzés: $\mathrm{DF}=$ szabadságfok, $\mathrm{M}=$ átlag, $\mathrm{SD}=$ szórás. $d_{\mathrm{RM}}=$ hatásméret mutató ismételt mérési (repeated measures) elrendezéshez. * Korreláció az adott önsértési módot megelőző és azt követő pozitív, illetve negatív érzelmek között. ** Az égetés esetében a statisztikai elemzések eredményeit - az alacsony mintaelemszám miatt - csak tájékoztató jelleggel közöljük.

\subsection{Az önsértés funkciói}

Az önsértés funkcióinak, azaz az önsértés hátterében álló lehetséges okoknak a vizsgálatkor a Claes és Vandereycken (2007b) által főkomponens analízissel meghatározott három nagy faktor mentén haladtunk. Mindegyik önsértési mód esetében meghatároztuk az (1) automatikus-pozitív megerősítő funkció, az (2) automatikus-negatív megerősítő funkció és a (3) pozitív szociális megerősítés skálák leíró statisztikai adatait (5. táblázat). A belső megbízhatóság mutatóját itt is csak azokban az esetekben számoltuk ki, ahol adott csoport mintaelemszáma elérte a 25 főt, azaz a karmolás, az ütés és a vágás esetében. Az Automatikus negatív megerősítés és a Szociális pozitív megerősítés skálák jó reliabilitás-értékekkel jellemezhetőek. Az Automatikus pozitív megerősítés skála vagy éppen megbízhatónak (ütés), vagy nem megbízhatónak (a karmolás és a vágás esetén) bizonyult, így ennek a skálának a belső megbízhatósága megkérdőjelezhető. A karmolás és az ütés 
esetében jellemző, hogy az önsértés azért történik, hogy az azt végző személy megszüntesse vagy csökkentse a negatív érzelmi állapotait. Mindez az égetés esetén kevésbé kifejezett motiváció. A karmolás hátterében továbbá kifejezett az önsértés figyelemfelhívó jellege, míg a vágás esetében ez az ok átlagosan kevésbé jellemző.

\begin{tabular}{|c|c|c|c|}
\hline 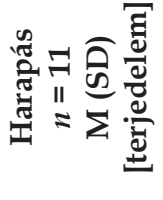 & 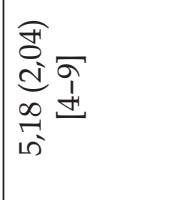 & 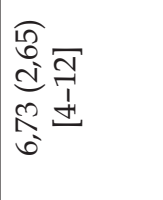 & 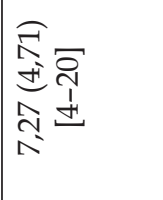 \\
\hline 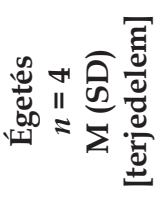 & 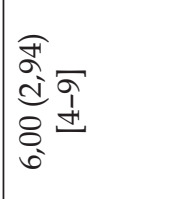 & 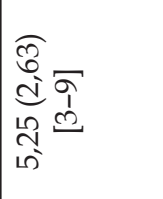 & 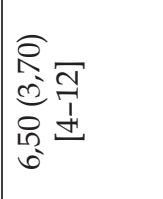 \\
\hline 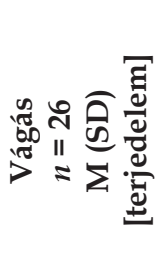 & 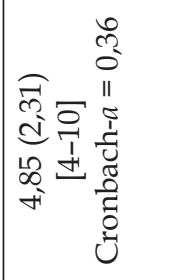 & 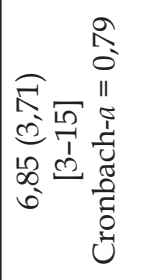 & 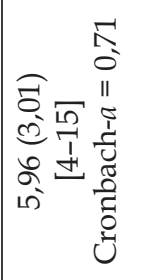 \\
\hline 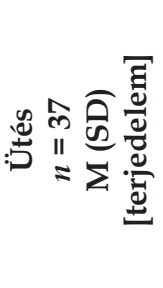 & 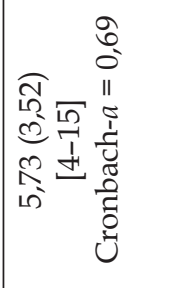 & 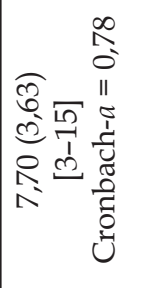 & 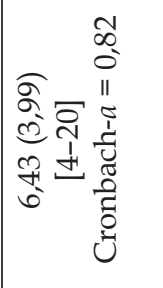 \\
\hline 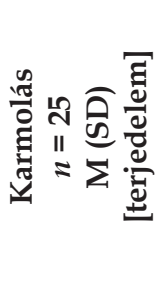 & 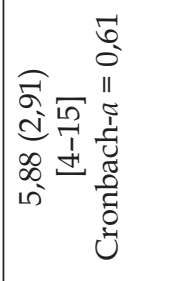 & 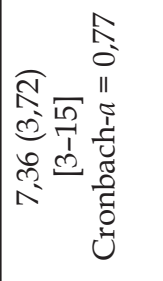 & 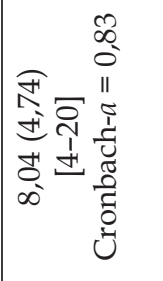 \\
\hline 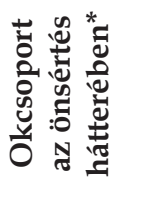 & 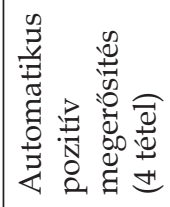 & 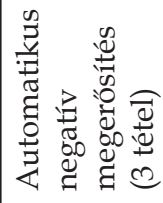 & 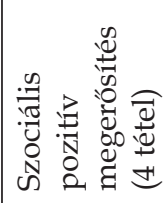 \\
\hline
\end{tabular}




\subsection{A vizsgálatban felhasznált egyéb mérőeszközök alapstatisztikája}

Mivel a nem szuicidális önsértést magyarázó kurrens modellek mindegyikében fontos szerephez jutnak az érzelemszabályozási folyamatok (pl. Chapman, Gratz, \& Brown, 2006; Nock \& Prinstein, 2004), illetve az NSSI cselekedetek megjelenésének jelentős rizikófaktorát képviselik a stresszteli negatív életesemények (pl. Liu és mtsai, 2014), ezért a SIQ-TR-HU konstruktumvaliditásának vizsgálatához ezeket az aspektusokat is felmértük. Ennek megfelelően vizsgáltuk az elmúlt fél évben a kamasszal történt negatív életeseményeket a család, a párkapcsolat és a barátság területén, továbbá a kognitív rugalmatlanságot és a disszociatív tendenciákat, mint - a legtöbb kontextusban és formában maladaptívnak tekintett (Braude, 2009) - érzelemszabályozási folyamatokat. A skálák teljes mintára és külön-külön a két nemre vonatkozó leíró statisztikai adatait a 6. táblázat tartalmazza.

6. táblázat. A vizsgálatban szereplő skálák

és azok alskáláinak leíró statisztikai mutatói

\begin{tabular}{|l|c|c|c|}
\hline \multicolumn{1}{|c|}{ Változó } & $\begin{array}{c}\text { Teljes minta } \\
(n=\mathbf{2 4 4}) \\
\mathbf{M}(\mathbf{S D})\end{array}$ & $\begin{array}{c}\text { Fiú } \\
(n=\mathbf{2 2 6}) \\
\mathbf{M}(\mathbf{S D})\end{array}$ & $\begin{array}{c}\text { Lány } \\
(n=\mathbf{1 8}) \\
\mathbf{M}(\mathbf{S D})\end{array}$ \\
\hline SÉK összpontszám & $12,60(6,66)$ & $12,15(6,58)$ & $18,23(4,92)$ \\
\hline SÉK Család alskála & $3,87(2,63)$ & $3,75(2,61)$ & $5,40(2,59)$ \\
\hline SÉK Párkapcsolat alskála & $3,58(2,39)$ & $3,50(2,40)$ & $4,44(2,23)$ \\
\hline SÉK Barátok alskála & $5,25(3,28)$ & $5,08(3,25)$ & $7,47(2,92)$ \\
\hline AFQ összpontszám & $20,66(6,92)$ & $20,21(6,63)$ & $26,33(8,16)$ \\
\hline ADES összpontszám & $82,31(61,13)$ & $80,39(61,13)$ & $106,39(57,41)$ \\
\hline ADES Disszociatív amnézia alskála & $20,03(16,48)$ & $19,61(16,42)$ & $25,33(16,81)$ \\
\hline ADES Abszorpció alskála & $17,41(13,51)$ & $16,88(13,39)$ & $24,11(13,53)$ \\
\hline ADES Passzív elszenvedés alskála & $14,62(12,07)$ & $14,33(12,08)$ & $18,28(11,69)$ \\
\hline ADES Derealizáció alskála & $30,25(25,15)$ & $29,58(25,06)$ & $38,67(25,39)$ \\
\hline
\end{tabular}

Megjegyzés: $\mathrm{M}$ = átlag, $\mathrm{SD}$ = szórás, SÉK = Serdülő Életesemény Kérdőív, AFQ = AFQ-Y8, Tapasztalati Elkerülés Kérdőív rövid formája, ADES = Serdülő Disszociatív Tapasztalatok Skála. 


\subsection{Az önsértő és a nem önsértő csoportok közötti különbségek a felmért változók tekintetében}

Felmértük azt is, hogy az egyes önsértó csoportok között a vizsgált változók mentén megjelennek-e különbségek. Három csoportot - a jelenleg is önsértóket (AÖ), a korábban önsértóket (KÖ) és a sohasem önsértő (SÖ) serdülőket - hasonlítottunk össze. Az egyszempontos varianciaanalízis - Tukeyféle utóelemzéssel kiegészített - eredményei szerint a jelenleg és a korábban önsértők között nem volt szignifikáns különbség az elmúlt fél évben átélt negatív életesemények átlagos számát tekintve, míg mindketten különböztek e tekintetben a sohasem önsértőktől, akik életében a legkevesebb stresszteli esemény történt az elmúlt hat hónapban. Ugyanezek az összefüggések voltak igazak a párkapcsolati negatív életeseményekre. A családban és a baráti kapcsolatokban történt stresszt okozó események számában csak a jelenleg is önsértók és a sohasem önsértők különböztek: az aktuálisan önsértők tapasztalják a több negatív életeseményt ezeken a területeken. A legmagasabb kognitív inflexibilitással a jelenleg önsértők jellemezhetők, míg a korábban önsértők és a sohasem önsértók e tekintetben nem különböztek. A disszociatív tendenciákat tekintve is a jelenleg önsértők mutatják a legmagasabb értékeket, de szignifikáns különbség csak közöttük és a korábban sohasem önsértők között van (részletesen ld. 7. táblázat). A hatásméret mutatók ( $\eta 2)$ közepes és magas mértéke az egyes csoportok között kifejezett különbségeket jelez.

7. táblázat. Az aktuálisan, a korábban és a sohasem önsértő csoportok összehasonlítása a felmért változók mentén

\begin{tabular}{|c|c|c|c|c|}
\hline Változó & $\begin{array}{c}\mathrm{AÖ}^{\mathrm{a}} \\
(n=64) \\
\mathrm{M}(\mathrm{SD})\end{array}$ & $\begin{array}{c}\mathrm{KÖ}^{\mathrm{b}} \\
(n=84) \\
\mathrm{M}(\mathrm{SD})\end{array}$ & $\begin{array}{c}\text { SÖc } \\
(n=96) \\
M(S D)\end{array}$ & $F(\mathrm{DF}) ; p ; \eta^{2}$ \\
\hline SÉK összpontszám & $15,20^{\complement}(7,50)$ & $13,3^{c}(5,76)$ & $10,20^{\mathrm{ab}}(6,03)$ & $\begin{array}{l}F(2)=9,16 ; \\
p<0,0001 \\
\eta^{2}=0,22\end{array}$ \\
\hline SÉK Család alskála & $4,36^{\mathrm{c}}(2,67)$ & $4,14(2,60)$ & $3,29^{\mathrm{a}}(2,57)$ & $\begin{array}{l}F(2)=3,48 \\
p=0,033 \\
\eta^{2}=0,06\end{array}$ \\
\hline $\begin{array}{l}\text { SÉK Párkapcsolat } \\
\text { alskála }\end{array}$ & $4,5^{\mathrm{c}}(2,50)$ & $3,95^{c}(2,26)$ & $2,59^{\mathrm{ab}}(2,07)$ & $\begin{array}{l}F(2)=14,67 \\
p<0,0001 \\
\eta^{2}=0,15\end{array}$ \\
\hline SÉK Barátok alskála & $6,47^{c}(3,63)$ & $5,12(2,95)$ & $4,55^{\mathrm{a}}(3,10)$ & $\begin{array}{l}F(2)=6,03 \\
p=0,003 \\
\eta^{2}=0,09\end{array}$ \\
\hline
\end{tabular}


7. táblázat folytatása

\begin{tabular}{|c|c|c|c|c|}
\hline Változó & $\begin{array}{c}\mathrm{AO}^{\mathrm{a}} \\
(n=64) \\
\mathrm{M}(\mathrm{SD})\end{array}$ & $\begin{array}{c}\mathrm{KÖ}^{\mathrm{b}} \\
(n=84) \\
\mathrm{M}(\mathrm{SD})\end{array}$ & $\begin{array}{c}S^{\mathrm{SO}} \\
(n=96) \\
\mathrm{M}(\mathrm{SD})\end{array}$ & $F(\mathrm{DF}) ; p ; \eta^{2}$ \\
\hline AFQ összpontszám & $23,30^{\text {bc }}(7,13)$ & $19,83^{\mathrm{a}}(6,24)$ & $19,64^{\mathrm{a}}(6,97)$ & $\begin{array}{l}F(2)=6,58 \\
p=0,002 ; \\
\eta^{2}=0,20\end{array}$ \\
\hline ADES összpontszám & $104,53^{c}(65,28)$ & $83,31(56,15)$ & $66,63^{\mathrm{a}}(58,26)$ & $\begin{array}{l}F(2)=7,82 \\
p=0,001 \\
\eta^{2}=0,57\end{array}$ \\
\hline
\end{tabular}

Megjegyzés: $\mathrm{DF}=$ szabadságfok, $\mathrm{M}=$ átlag, $\mathrm{SD}$ = szórás. A felső indexben jelzett csoportok közötti különbségek minimum $p<0,05$ szinten szignifikánsak. $\eta^{2}=$ hatásméret mutató: 0,040-ig kis hatásméret; 0,060 és 0,110 között közepes hatásméret; 0,140-től erős hatásméret (Pierce, Block, \& Aguinis, 2004). SÉK = Serdülő Életesemény Kérdőív, AFQ = AFQ-Y8, Tapasztalati Elkerülés Kérdóív rövid formája, ADES = Serdülő Disszociatív Tapasztalatok Skála. $\mathrm{AÖ}=$ aktuálisan önsértő (az önsértés egy hónapon belül történt), KÖ = korábban önsértő (az önsértés legalább egy hónappal korábban történt), SÖ = sohasem volt önsértő.

\subsection{Az önsértés összefüggései a vizsgált változókkal}

Pearson-féle korrelációs elemzés Bonferroni-korrekcióval történő alkalmazásával megvizsgáltuk, hogy az aktuális önsértés megléte, illetve az önsértési módok száma milyen összefüggésben van a többi felmért változóval. Eredményeink szerint a jelenlegi önsértó státusz az elmúlt fél évben a párkapcsolatban átélt negatív életeseményekkel és a kognitív rugalmatlansággal függött össze enyhe mértékben. Az együttjárás pozitív, azaz minél több stresszes eseményt él meg a kamasz párkapcsolatában, illetve minél erőteljesebb az érzelmek, emlékek, gondolatok elnyomása, annál valószínúbb az önsértés előfordulása. Az önsértési módok száma nem mutatott szignifikáns lineáris kapcsolatot egyetlen változóval sem, ahogyan az életkor sem állt szignifikáns kapcsolatban semelyik másik változóval. A korrelációs mátrix a 8. táblázatban található. 


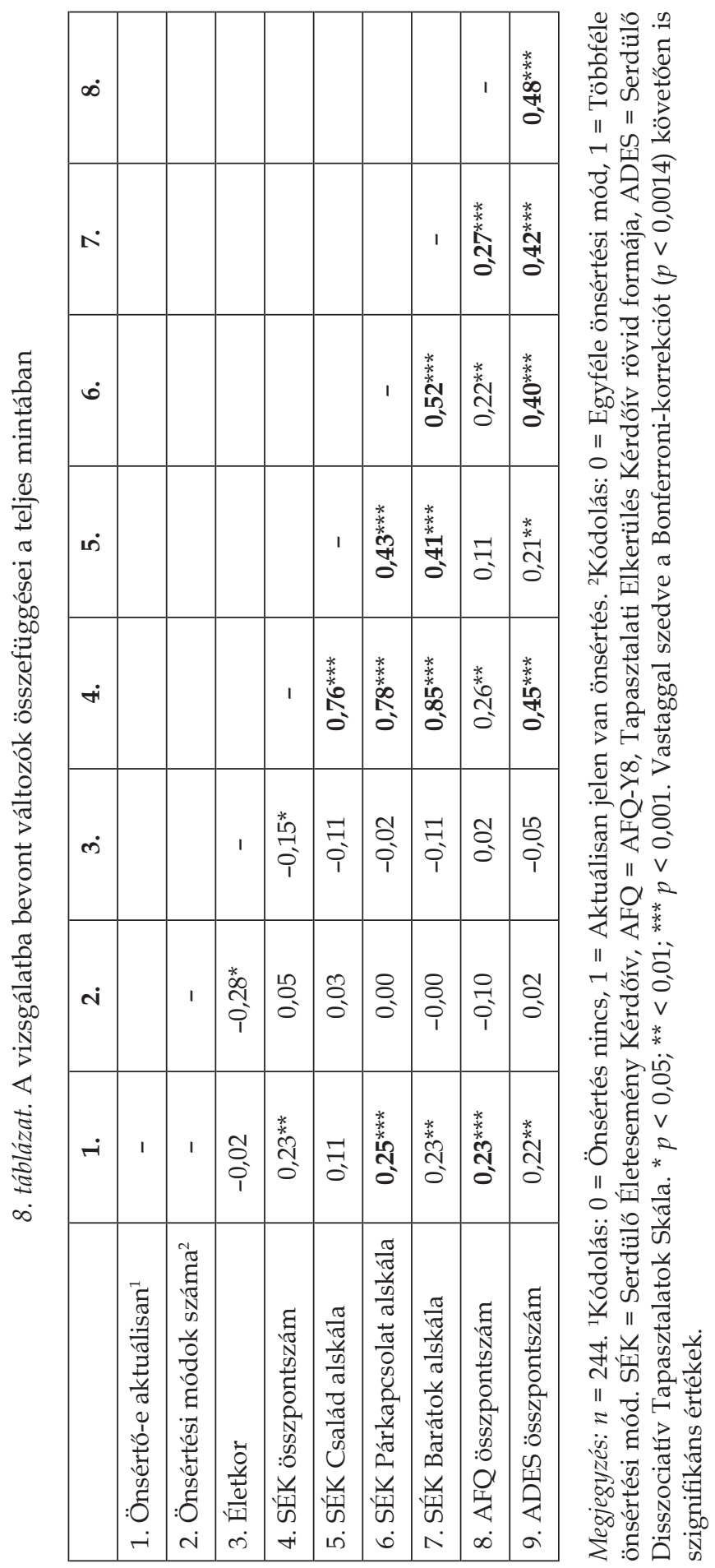




\section{Megbeszélés}

A tanulmány a Kezelésközpontú Önsértés Kérdőív (SIQ-TR) magyar nyelvre történő adaptációs munkálatait foglalta össze. Az összetett felépítésú kérdőív hazai vizsgálatát egy speciális populációban, javítóintézeti neveltek mintáján végeztük. Az eredeti kérdőív (Self-Injury QuestionnaireTreatment Related; SIQ-TR; Claes \& Vandereycken, 2007b) a nem öngyilkossági szándékkal történő önsértés felmérését elsősorban klinikai populációkban célozta meg, azonban később normatív mintákon is igazolták annak alkalmazhatóságát a kutatásban (pl. Braga \& Gonçalves, 2014; Claes \& Muehlenkamp, 2013). A SIQ-TR a különbözó módú önsértő viselkedéseket azok komplexitásában kívánja megragadni (pl. az önsértéshez kapcsolódó attitúdök, érzelmek, okok felmérésével), ezért alkalmazása a klinikumban az egyéni pszichodiagnosztikai folyamat szerves részét képezheti. Ugyanakkor a méróeszköz az önsértéssel kapcsolatos populációs felmérések során is jól alkalmazható (Claes \& Vandereycken, 2007b).

Tapasztalatunk alapján a Kezelésközpontú Önsértés Kérdőív magyar nyelvú változatának (SIQ-TR-HU) kérdéseit a vizsgálatba bevont serdülók általánosságban megértették a mintában gyakorta tapasztalható tanulási, olvasási és szövegértési nehézségek ellenére is. A kérdőív IV. nagyobb tematikai egységénél (az önsértéshez vezető okokra vonatkozó kérdésekre történő válaszadás során) észleltük azt, hogy annak értelmezése bizonyos esetekben segítséget igényelhet ebben a speciális, számos szempontból hátrányos helyzetú populációban.

Eredményeink szerint a javítóintézeti neveltek körében a nem szuicidális önsértés életprevalencia értéke rendkívül magas, a minta közel kétharmadát érinti. Ez az érték kétszer olyan magas, mint hasonló populációban végzett külföldi vizsgálatokban (pl. Kenny Lennings, \& Munn, 2008; Knight, Coid, \& Ullrich, 2017). Aktuálisan - az elmúlt egy hónapos időtartamban a magyar minta egynegyede végzett valamilyen önsértő cselekedetet. A jelenség részletes felmérésére a SIQ-TR-HU jó alapot nyújthat.

Ahogyan korábbi, serdülő és felnőtt rabok körében végzett felmérésekben (pl. Kenny és mtsai, 2008) feltárták, a leggyakoribb önsértési formák mintánkban is az ütés, a vágás és a karmolás voltak. Legritkábban az égetés fordult elő, az is kizárólag fiúknál. Bizonyos önsértési módok alkalmazásában tehát nemi különbségek is megjelenhetnek. Ez összefüggésben állhat az önsértési metódus radikalitásával és/vagy szociális aspektusaival is: az önégetés erőteljesebb forma, amely a társas közegbeli pozíciót erősítheti zárt intézményi közegben. Ennek tisztázása további vizsgálatot igényel. Az aktuálisan önsértők $60 \%$-ára egyféle önsértési forma jellemzó, 40\%-uk egyszerre többféle önsértési módot is alkalmaz. Elemzéseinkból azonban kiderült, hogy az önsértési módok száma egyik mért pszichológiai változóval 
sincs lineáris kapcsolatban, egyedül az életkorral mutat gyenge, negatív irányú együttjárást. Ennek fényében feltételezhető, hogy javítóintézeti kamaszok körében - ellentétben normatív serdülőmintákkal (pl. Zetterqvist, Lundh, Dahlström, \& Svedin, 2013) - az önsértés más komponensei (pl. az önsértés gyakorisága) állhatnak kapcsolatban az önsértés jellegzetes rizikófaktoraival (pl. negatív életesemények, érzelemszabályozási deficitek).

A leggyakrabban megsértett testfelületek a szó szerint „kézre eső" területek, a karok, kezek és a feji, illetve nyaki rész. Ezek a területek ugyanakkor a legnehezebben elrejthetők külső szemlélők számára. Ezzel felvetődik, hogy a javítóintézeti neveltek részben azért folytathatnak önsértő viselkedést, hogy felhívják magukra a (felnőtt) környezet figyelmét (önsértés mint kommunikatív tett), hogy előnyöket szerezzenek vagy enyhítsenek fogvatartásuk körülményein (önsértés mint a környezet feletti kontroll eszköze).

Az önsértéssel asszociálódó szubjektív fájdalomélmény általánosságban mintánkban is alacsony, illetve közepes mértékú (vö. pl. Claes \& Vandereycken, 2007b). Az önsértés közbeni magas fájdalomküszöb disszociatív és a fájdalmi ingerekhez való erőteljesebb habituációs mechanizmusok múködését implikálja (Glenn, Michel, Franklin, Hooley, \& Nock, 2014). Glenn és munkatársai (2014) az alacsony szubjektív fájdalomtapasztalatot összefüggésbe hozták továbbá a fokozott önkritikusság jelenlétével. Ennek hatását támasztja alá Hooley és St. Germain (2014) vizsgálata is. A fokozott önkritikussággal társuló negatív érzések, kifejezetten a búntudat, értéktelenségérzés, alacsony önbizalom olyan lélektani állapotot eredményezhetnek - hasonlóképpen a disszociáció mechanizmusához - amelynek során az indulatok levezetésére az önsértés, mint önbüntetés mintegy automatikus, habituálódott válaszként jelenik meg. Ebben az állapotban a fájdalomküszöb emelkedni tud. A javítóintézeti mintában a feltehetően alacsony fokú tudatosság, a kognitív rugalmatlanság felerősítheti a bezárt kamasz önmagával szembeni haragját, így a pszichológiai ellátás során a neveltek önmaguk felé irányuló negatív érzéseit kifejezetten fontos lenne feltárni és átdolgozni. Az önsértés önbüntető és öndestruáló szerepét több korábbi vizsgálat is megerősítette (pl. Brown és mtsai, 2002). Felvetődik az a lehetóség is, hogy a fájdalomanalgézia önmagában rizikófaktor az önsértésre (Glenn és mtsai, 2014).

Az önsértés attitüdinális komponenseit (tervezettség, tudatosság, sebek ellátása, cselekmény eltitkolása) az egyes önsértési módok tekintetében jellemeztük. Az önsértéshez kapcsolódó érzelmi, gondolkodási és viselkedéses szegmensek eltéró mértékben jellemezhetik az egyes önsértési technikákat. A tervezettség ugyan mindegyik önsértési mód esetében átlagosan alacsony fokú mintánkban, azonban az ütés, a harapás és az égetés kifejezetten tervezetlenül jelentkezik. Az önsértés a kutatások eredményei (pl. Black \& 
Mildred, 2014) szerint erőteljesen asszociálódik az impulzivitással, kifejezetten annak „sürgetettség” dimenziójával, amely az erós negatív érzelmek következtében hirtelen megjelenő viselkedésekre utal (Whiteside \& Lynam, 2001). Bizonyos önsértési módok esetében ez még kifejezettebb lehet. Az ütés, a harapás és az égetés önsértési módjai radikálisabb formák lehetnek, impulzívabb megjelenésüket ez is magyarázhatja. Az önsértő cselekedetre való tudatos rálátás a karmolás és az ütés esetében vizsgálati mintánkban átlagosan magasabb fokú, az égetés során pedig nagyon alacsony. Hasonlóképpen, a karmolást követően például jellemzőbb a sebek ellátására való törekvés, míg égetést és harapást követően kevéssé. Ezzel felvetődik, hogy bizonyos önsértési módok erőteljesebben kapcsolódhatnak disszociatív mechanizmusokhoz. Adataink az önsértéshez fúződő attitűdöket tekintve hasonló mintázatot mutatnak Claes és Vandereycken (2007b) evészavaros nők körében végzett felmérésével. Ugyanakkor Claes és Vandereycken (2007b) vizsgálatától eltérően, ahol a tett eltitkolásának igénye kifejezett volt, mintánkban az önsértés jeleinek elrejtésére való törekvés mindegyik önsértési mód esetében alacsony szintúnek bizonyult. Mindez megerősíti azt a fentebb felvetett lehetőséget, hogy javítóintézeti közegben az önsértés, legalábbis annak testi következményei, jelentős kommunikatív szereppel bírnak: jelezhetik például a szenvedés vagy a „keménység”, az ellentartás mértékét a társak és/vagy a nevelők felé, de segítségkéró üzenetük is lehet. Mindennek mélyebb, részletesebb vizsgálata például félig strukturált interjútechnikával történhet meg.

A Claes és Vandereycken (2007b) által főkomponens elemzéssel azonosított két negatív érzelmiállapot-csoport - önsértés előtti és önsértés utáni negatív emóciók - mintánkban is egyértelmúen kirajzolódott mind az öt önsértési mód esetében. Átlagosan a legtöbb negatív érzelem a karmolás és az ütés előtt és után jelenik meg, míg az égetés előtti és utáni állapothoz kapcsolódik a legkevesebb negatív érzés. Ez összefüggésben állhat azzal is, hogy az égetés a legkevésbé eltervezett és elkövetése a legalacsonyabb tudatossággal bír az összes vizsgált önsértési mód közül. Ez a mintázat erőteljesebb disszociatív folyamatokat vethet fel az égetés esetében. Fontos azonban megjegyeznünk, hogy ez az önsértési mód a legritkább a mintában, az alacsony elemszám az eredmények interpretálhatóságát jelentősen korlátok közé szorítja.

A pozitív érzelmek esetében a skálák (pozitív érzelmek önsértés előtt és pozitív érzelmek önsértést követően) csak a karmolás esetén bizonyultak megbízhatónak, az égetés és a harapás esetén az alacsony mintaelemszám miatt pedig nem teszteltük a skálák belső megbízhatóságát. A legkevesebb pozitív érzelem - hasonlóképpen a negatív érzelmi állapotokhoz - az égetés után jelenik meg. Mindez tovább erősíti azt a feltételezést, hogy az egyes önsértési technikákhoz - részben - eltéró intenzitású érzelemi állapotok kapcsolódnak. 
Fontos azt is megjegyezni, hogy az egyes önsértési módoknál azt is teszteltük, hogy a két nagy érzelmi állapotkörben (negatív érzelmek, pozitív érzelmek) történik-e változás az önsértés során. Az eredmények szerint sem a negatív, sem a pozitív érzelmek intenzitása nem változik számottevően az önsértést követően az önsértés előtti állapothoz képest. Egyedül a harapás módszerénél tudtunk kimutatni tendenciaszintú növekedést a pozitív érzelmek és tendenciaszintú csökkenést a negatív érzelmek esetében. Ezek az eredmények azt sugallják, hogy - bár az önsértés egyik szándékolt célja az érzelmi állapotok módosítása (pl. Andover \& Morris, 2014) - az önsértő cselekedet nem tölti be ezt a funkcióját, azaz érdemben nem vezet a pozitív érzelmek emelkedéséhez és a negatív érzelmi állapotok redukciójához. Eredményeink értelmezésénél ugyanakkor figyelembe kell vennünk az alacsony mintaelemszám mellett, hogy a kitöltók az önsértő tett előtt és után megjelenó érzelmi állapotukat retrospektíven ítélték meg. Mindez valós idejú változás felmérését nem teszi lehetővé, ugyanakkor kutatásunk rámutat az ilyen jellegú mérések, illetve vizsgálati elrendezés (pl. naplómódszer, élményértékelő mintavételi eljárás [experience sampling method, ESM]) megtervezésének fontosságára a jövőben.

Az önsértés hátterében álló okcsoportok mintabeli elemzéséhez a Claes és Vandereycken (2007b) által azonosított három faktort vettük alapul, amely Nock és Prinstein $(2004,2005)$ teoretikus rendszerezését követi. Míg a szociális pozitív megerósítő és az automatikus negatív megerősítő funkció a karmolás, az ütés és a vágás esetében is megbízható skálának bizonyult, addig az automatikus pozitív megerősítő funkció csupán az ütésnél közelítette meg az elfogadható belsó megbízhatóságot. Mindezt figyelembe véve az önsértés hátterében álló automatikus pozitív megerősítés kapcsán következtetéseket nem tudunk levonni. További vizsgálatok mutathatnak rá arra, hogy a SIQ-TR-HU alkalmas-e az önsértés önstimulatív funkciójának, azaz annak a mérésére, hogy az önsértő tett hátterében valamely vágyott érzelmi állapot elérésének motivációja áll. Az automatikus negatív megerősítés, azaz a negatív érzelmi állapotok csökkentésének, az önmegnyugtatásnak a motivációja a karmolás és az ütés esetében a legjellemzőbb, közepes mértékú. Mindez párhuzamba állítható azzal, hogy ehhez a két önsértési módhoz kapcsolódott a legtöbb negatív érzelem az önsértés előtt és után. Feltehetően a karmolás és az ütés az azokat végzők előzetes elvárásai szerint a felgyülemlett negatív érzéseket csökkenteni fogják, ugyanakkor - ahogy fentebb kirajzolódott - ez a várt megkönnyebbülés mégsem következik be. Az önsértés pszichológiai kezelésében a negatív érzelmi állapotok alkalmazkodást segítő feldolgozása és annak tudatosítása - például edukációval - hogy az önsértó cselekedet valójában nem hoz kedvező változást az érzelmi állapotokban, és az elviselhetetlennek túnő érzést kiváltó problémahelyzet sem szúnik meg az önsértő cselekedettel, kiemelt szerepet kell, hogy kapjon. 
Az önsértés figyelemfelkeltő vonatkozása, azaz a szociális pozitív megerősítés is megjelent mintánkban mind az öt önsértési mód kapcsán. Ugyanakkor az átlagértékek alacsonyak, ez a funkció nem értékelhetó kifejezett - tudatosan reflektált - motivációként a javítóintézeti neveltek önsértésének hátterében. Ez egybecseng Claes és Vandereycken (2007b) adataival, illetve azzal a trenddel, hogy a kutatásokban az önsértés automatikus pozitív és negatív funkcióit jóval gyakrabban igazolják, mint a szociális motivációkat (pl. Brackman \& Andover, 2017). Ez igaz a büntetés-végrehajtási közegben kapott eredményekre is (pl. Morales \& Guarnero, 2014). Összességében kutatásunk elsődlegesen az önsértés érzelemregulációs hátterére mutat rá összhangban több, büntetés-végrehajtási intézményben végzett vizsgálattal (pl. Morales \& Guarnero, 2014). Power, Smith és Beaudette (2016) félig strukturált interjúk tartalomelemzésével pedig arra is rámutattak, hogy bár az önsértés mögött meghúzódó motivációk hasonlóak bebörtönzött és a szabad emberek körében, az egyes okcsoportok gyakoriságában eltérés mutatkozik: a szociális pozitív megerősítés például kevésbé gyakori rabok között, mint nem rabok körében.

Az önsértéssel asszociálódó tényezők azonosítása, egyben az önsértés kérdőív konvergens validitásának tisztázása céljából felmértük a mintát érintő közelmúltbeli negatív életeseményeket, valamint az érzelemszabályozás két aspektusát is. Ezeket az értékeket továbbá összehasonlítottuk az aktuálisan, a korábban és a sohasem önsértők csoportjaiban. A mintában az aktuálisan és a korábban önsértők a vizsgálatot megelőző fél évben szignifikánsan több negatív életeseménnyel szembesültek, mint a sohasem önsértôk, kifejezetten párkapcsolati színtéren. A jelenleg önsértők élték át továbbá a legtöbb stresszteli eseményt a családi és a baráti közegben is. A korábbi kutatásokkal összhangban (pl. Liu és mtsai, 2014) javítóintézeti populációban is az önsértés jelentős rizikófaktorának bizonyulnak a közelmúltbeli negatív életesemények. Az ezek kapcsán megjelenő stressz maladaptív levezetési formáját jelentheti az önsértés folyamata. Ez különösen igaz lehet a javítóintézeti közegre, ahol a nevelteknek jóval kevesebb lehetősége adódik aktív problémamegoldásra (pl. a családtól, a pártól való távolság miatt). A korrekciós közegbe kerülés elvágja a neveltek számára a napi kapcsolatot párjukkal, a serdülőkorban egyre fontosabbá váló partnerkapcsolat megteremtésének lehetősége is jelentősen korlátozott. Másrészt érdemes megemlíteni, hogy a tesztfelvételt követő beszélgetésekből kiderült, a javítóintézeti neveltek egy részének már gyermeke is van, akivel/akikkel az intenzív találkozás ellehetetlenült. A fontos kötődési személyekkel kapcsolatos nehézségek vagy éppen a párkapcsolat hiánya jelentős stresszforrást képviselhet a bezárt - és alapvetően jórészt veszélyeztetett - kamaszok számára, ami megnöveli az indulatok önmaguk felé fordításának esélyét, önsértésben manifesztálódva. 
A negatív tapasztalatok - negatív élmények, érzések, gondolatok, emlékek - elnyomása, valamint a realitástól való eltávolodás, a tapasztalatok és a viselkedés problémás integrációja eredményeink szerint együtt jár az önsértéssel. Az aktuálisan önsértők a legmagasabb disszociációval és tapasztalati elkerüléssel, azaz a különböző élmények magas fokú elnyomásával, ezzel egyfajta kognitív rugalmatlansággal jellemezhetők, ahogyan az korábbi kutatási adatokban is körvonalazódott (pl. Brereton \& McGlinchey, 2019). Ezzel kapcsolatban érdemes azokra a kutatási eredményekre is rámutatni, amelyek szerint az erőteljes tapasztalati elkerülés, kognitív rugalmatlanság magasabb internalizáló tünetképzéssel (fokozódó szorongással, depresszív tünetekkel) társul (pl. Renshaw, 2016). A depresszív és szorongásos tünetképződés szerepét az önsértés folyamatában további kutatások tisztázhatják.

A fentiek alapján az önsértés pszichológiai megelőzésében és ellátásában további olyan szempontoknak is fontos volna hangsúlyt kapnia, mint (1) a közelmúltbeli negatív életesemények felmérése és azok aktív feldolgozási lehetősége. Ez a javítóintézeti közegben jelentheti például azt, hogy megteremtik annak a lehetőségét, hogy - pl. mediációs technikákkal - a nevelt a párjával együtt aktíva(bba)n vegyen részt kapcsolati problémáik megoldásában. (2) A negatív élmények elnyomására való hajlandóság csökkentése (azaz a tapasztalati elkerülés leépítése) például kognitív viselkedésterápiás technikákkal (pl. dialektikus viselkedésterápiával vagy sématerápiával; Brereton \& McGlinchey, 2019). (3) Olyan, az alkalmazkodást segító érzelemszabályozási stratégiák facilitálása, mint a figyelem átirányítása negatív eseményekről a pozitív aspektusokra vagy a helyzet megoldásának eltervezése interperszonális stresszhelyzetekben. Ebben a folyamatban a mentalizáció alapú terápiák (mentalization-based therapy, MBT) alkalmazása fontos eszköz lehet: a saját mentális állapotok (és a másik mentális állapotainak) tudatosítása és nyomon követése feltöltheti az önsértéshez hozzájáruló mentalizációs hiányokat. Az önsértéssel asszociálódó elkerülésfókuszú érzelemszabályozási mechanizmusok (jelen vizsgálatban a disszociatív múködésmód és a fokozott tapasztalati elkerülés) olyan érzelemregulációs deficitek, amelyeket a mentalizációs készség fejlesztésével korrigálni lehet (pl. Rossouw \& Fonagy, 2012).

Vizsgálatunk korlátai közé tartozott - annak ellenére, hogy egy adott tanév során a magyarországi javítóintézeti neveltek jelentős részét elértük a viszonylag alacsony mintaelemszám, különösen a nemekre lebontott aktuális önsértő státuszt tekintve. Ugyanakkor a minta speciális jellemzői miatt a nemi összetétel arányai adottak voltak. A mintaelemszámmal kapcsolatos további nehézség volt, hogy az egyes önsértési csoportokban (karmolás, ütés, vágás, égetés és harapás) semelyik esetben sem érte el az 50 főt az elemszám. Megbízhatósági mutatókat csak olyan esetekben számoltunk, ahol adott csoport mintaelemszáma elérte a 25 fôt (karmolás, ütés és vágás). 
Az alacsony elemszám és az egyes önsértési módok esetenkénti komorbiditása miatt megerősítő faktorelemzést sem tudtunk végezni az önsértést megelőző és követó érzelmi skálák, valamint az önsértés funkciója skálái kapcsán. Az alacsony mintaelemszám a statisztikai erő csökkenését eredményezte, ami az eredmények interpretálhatóságát korlátok közé szorítja. Szintén ronthatja az eredmények értelmezhetőségét a javítóintézeti populációban általában magas arányban előforduló tanulási, szövegértési nehézségek jelenléte, a mintára jellemző alacsony iskolázottsági szint (KSH, 2014). Mindezt a gondos, akár négyszemközti kitöltetés segítségével kívántuk kompenzálni: a képzett tesztfelvevők a fiatalok segítségére voltak, amenynyiben azok azt igényelték. A kérdőívkitöltést követően lehetőség volt továbbá a kutatásvezetókkel való beszélgetésre is. Vizsgálatunk további hiányossága, hogy - etikai okokból - nem gyújtöttünk adatot a fiatalok esetleges korábbi vagy jelenlegi pszichiátriai betegségéról, illetve ellátásáról. A vizsgálat keresztmetszeti jellegéból adódóan arra sem volt lehetóségünk, hogy a különböző külső validáló változók és az önsértés között ok-okozati kapcsolatokat vizsgálhassunk. Ennek megfelelően nem tudtunk arra sem rámutatni, hogy a tapasztalati elkerülés vagy a disszociáció az önsértést megelőzően, közben és/vagy azt követően van-e jelen. A SIQ-TR kérdőív retrospektív jellegéből fakadóan továbbá torzító hatás merülhet fel az önsértés érzelmi és attitüdinális komponenseit tekintve: kérdéses, hogy a kitöltők mennyire tudtak pontosan visszaemlékezni az önsértő cselekedet elókészületeivel kapcsolatos részletekre. Kérdéses lehet az is, hogy egy pszichésen fokozottan sérülékeny csoport, mint amilyen vizsgált mintánk is, mennyire pontosan képes az érzelmek intenzitásának megítélését különválasztani az önsértő tett előtt és azt követóen. Ezzel összefüggésben az érzelmek differenciált észlelésének, azonosításának, az azokról való beszámolás nehézségének lehetséges problémái is befolyásolhatták az eredményeket. Felvetődik továbbá, hogy az érzelmek felismerését és jellemzését áthathatja egy önbeteljesítő torzító hatás is: azaz például ha valaki azért végez önsértést, hogy negatív érzéseit csökkentse, akkor - annak érdekében, hogy ezt a motivációt megerősítse - később arról számolhat be, hogy úgy érezte, csökkent a negatív érzelmek nyomása az önsértést követóen.

A fenti korlátok mellett összességében a SIQ-TR-HU mind egyéni ellátás keretében (pl. a klinikumban vagy a tanácsadás folyamatában), mind csoportos formában (pl. az önsértés prevenciójára vagy intervenciójára fókuszáló iskolapszichológiai szúrés, illetve programok keretében), továbbá a kutatómunkában, a nem szuicidális önsértés részletes felmérésére egyaránt jól alkalmazható, informatív, valid és megbízható mérőeszköz. Bevezetése a hazai tesztállományba segíti a nem öngyilkossági szándékkal történő önsértés komplex felmérését, elemzését és alapvető információkat nyújthat célzott terápiás intervenciók megtervezéséhez is. 


\section{Irodalom}

Abela, J.R.Z., \& Hankin, B.L. (2011). Rumination as a vulnerability factor to depression during the transition from early to middle adolescence: A multiwave longitudinal study. Journal of Abnormal Psychology, 120, 259-271.

American Psychiatric Association (2000). Diagnostic and Statistical Manual of Mental Disorders - Text Revision (DSM-IV-TR). Washington DC: Americal Psychiatric Association

American Psychiatric Association (2013). Diagnostic and Statistical Manual of Mental Disorders, 5th ed. Washington DC: Americal Psychiatric Association

Andover, M.S., \& Gibb, B.E. (2010). Nonsuicidal self-injury, attempted suicide, and suicidal intent among psychiatric inpatients. Psychiatry Research, 178, 101-105.

Andover, M.S., \& Morris, B.W. (2014). Expanding and clarifying the role of emotion regulation in nonsuicidal self-injury. Canadian Journal of Psychiatry, 59(11), 569-575.

Armstrong, J., Putnam, F.W., Carlson, E., Libero, D., \& Smith, S. (1997). Development and validation of a measure of adolescent dissociation. The Adolescent Dissociative Experience Scale. Journal of Nervous and Mental Disease, 185, 491-497.

Black, E.B., \& Mildred, H. (2014). A cross-sectional examination of non-suicidal self-injury, disordered eating, impulsivity, and compulsivity in a sample of adult women. Eating Behaviors, 15, 578-581.

Brackman, E.H., \& Andover, A.S. (2017). Non-suicidal self-injury. In D. McKay, D.S. Abramowitz, \& E.A. Storch (Eds.), Treatments for psychological problems and syndromes (1st ed., 328-344). Wiley Blackwell

Braga, C., \& Gonçalves, S. (2014). Non-suicidal self injury, psychopathology and attachment: A study with university students. Spanish Journal of Psychology, 17, e66, 1-7.

Braude, S. (2009). The conceptual unity of dissociation: A philosophical argument. In P. Dell, \& J. O'Neil (Eds.), Dissociation and the dissociative disorders: DSM-V and beyond (27-36). New York: Routledge

Brereton, A., \& McGlinchey, E. (2019). Self-harm, emotion regulation, and experiential avoidance: A systematic review. Archives of Suicide Research, Article ID 30636566. Doi: 10.1080/13811118.2018.1563575

Briere, J., \& Gil, E. (1998). Self-mutiliation in clinical and general population samples: Prevalence, correlates, and functions. American Journal of Orthopsychiatry, 68, 609-620.

Brown, M.Z., Comtois, K.A., \& Linehan, M.M. (2002). Reasons for suicide attempts and nonsuicidal self-injury in women with borderline personality disorder. Journal of Abnormal Psychology, 111, 198-202.

Chapman, A.L., Gratz, K.L., \& Brown, M.Z. (2006). Solving the puzzle of deliberate selfharm: The experiential avoidance model. Behaviour Research and Therapy, 44, 371-394.

Claes, L., \& Vandereycken, W. (2007a). Self-injurious behavior: Differential diagnosis and functional differentiation. Comprehensive Psychiatry, 48, 137-144.

Claes, L., \& Vandereycken, W. (2007b). The Self-Injury Questionnaire-Treatment Related (SIQ-TR): Construction, reliabilty, and validity in a sample of female eating disorder patients. In P.M. Goldfarb (Ed.), Psychological tests and testing research trends (111-139). New York: Nova Science Publishers

Claes, L., \& Muehlenkamp, J. (2013). The relationship between the UPSS-P impulsivity dimensions and nonsuicidal self-injury characteristics in male and female high-school students. Psychiatry Journal, Article ID 654847. Doi: 10.1155/2013/654847

Davey, A., Arcelus, J., Meyer, C., \& Bouman, W.P. (2016). Self-injury among trans individuals and matched controls: Prevalence and associated factors. Health and Social Care in the Community, 24(4), 485-494. 
Dixon-Gordon, K., Harrison, N., \& Roesch, R. (2012). Non-suicidal self-injury within offender populations: A systematic review. International Journal of Forensic Mental Health, 11, 33-50.

Farrington, A., Waller, G., Smerden, J., \& Faupel, A.W. (2001). The Adolescent Dissociative Experiences Scale: Psychometric properties and difference in scores across age groups. The Journal of Nervous and Mental Disease, 189, 722-727.

Favazza, A. (1986). Self-harm behavior survey. Columbia, MI: Author

Favazza, A., Rosenthal, R.J. (1993). Diagnostic issues in self-mutilation. Hospital and Community Psychiatry, 44(2), 134-140.

Garnefski, N., \& Kraaij, V. (2006). Cognitive emotion regulation questionnaire - development of a short 18-item version (CERQ-short). Personality and Individual Differences, 41, 10451053.

Garnefski, N., Kraaij, V., \& Spinhoven, P. (2001). Negative life events, cognitive emotion regulation, and emotional problems. Personality and Individual Differences, 30, 1311-1327.

Glenn, J.J., Michel, B.D., Franklin, J.C., Hooley, J.M., \& Nock, M.K. (2014). Pain analgesia among adolescent self-injurers. Psychiatry Research, 220(3), 921-926.

Gratz, K.L. (2001). Measurement of deliberate self-harm: preliminary data on the Deliberate Self-Harm Inventory. Journal of Psychopathology and Behavioral Assessment, 23(4), 253-263.

Greco, L.A., Lambert, W., \& Baer, R.A. (2008). Psychological Inflexibility in Childhood and Adolescence: Development and Evaluation of the Avoidance and Fusion Questionnaire for Youth. Psychological Assessment, 20(2), 93-102.

Hamza, C.A., Stewart, S.L., Willoughby, T. (2012). Examining the link between nonsuicidal self-injury and suicidal behavior: A review of the literature and an integrated model. Clinical Psychology Review, 32, 482-495.

Hankin, B.L., \& Abramson, L.Y. (2002). Measuring cognitive vulnerability to depression in adolescence: Reliability, validity, and gender differences. Journal of Clinical Child and Adolescent Psychology, 31, 491-504.

Hankin, B.L., Stone, L.B., \& Wright, P.A. (2010). Co-rumination, interpersonal stress generation, and internalizing symptoms: Sex differences and transactional influences in a multi-wave study of adolescents. Development and Psychopathology, 22, 217-235.

Herpertz, S. (1995). Self-injurious behaviour: Psychopathological and nosological characteristics in subtypes of self-injurers. Acta Psychiatrica Scandinavica, 91, 57-68.

Hooley, J.M., \& St. Germain, S.A. (2014). Nonsuicidal self-injury, pain, and self-criticism: Does changing self-worth change pain endurance in people who engage in self-injury? Clinical Psychological Science, 2(3), 297-305.

Houben, M., Claes, L., Vansteelandt, K., Berens, A., Sleuwaegen, E., \& Kuppens, P. (2017). The emotion regulation function of nonsuicidal self-injury: A momentary assessment study in inpatients with borderline personality disorder features. Journal of Abnormal Psychology, 126(1), 89-95.

In-Albon, T., Ruf, C., \& Schmid, M. (2013). Proposed diagnostic criteria for the DSM-5 of nonsuicidal self-injury in female adolescents: Diagnostic and clinical correlates. Psychiatry Journal, Article ID 159208. Doi: 10.1155/2013/159208

Kenny, D.T., Lennings, C.J., \& Munn, O.A. (2008). Risk factors for self-harm and suicide in incarcerated young offenders: implications for policy and practice. Journal of Forensic Psychology Practice, 8(4), 358-382.

Kisiel, C.L., \& Lyons, J.S. (2001) Dissociation as a mediator of psychopathology among sexually abused children and adolescents. American Journal of Psychiatry, 158, 1034-1039.

Klonsky, E.D. (2011). Non-suicidal self-injury in United States adults: Prevalence, sociodemographics, topography and functions. Psychological Medicine, 41, 1981-1986. 
Klonsky, E.D., Oltmanns, T.F., \& Tukrheimer, E. (2003). Deliberate self-harm in a nonclinical population: Prevalence and psychological correlates. American Journal of Psychiatry, 160, 1501-1508.

Knight, B., Coid, J., \& Ullrich, S. (2017). Non-suicidal self-injury in UK prisoners. International Journal of Forensic Mental Health, 16(2), 172-182.

KSH (Központi Statisztikai Hivatal) (2014). A javítóintézeti nevelésról. Statisztikai Tükör, 99, 1-7.

KSH (Központi Statisztikai Hivatal) (2019). Javítóintézetben elhelyezettek (2015-). Letöltve: 2019. 12. 23-án: https://www.ksh.hu/docs/hun/xstadat/xstadat_eves/i_fsg014.html

Liu, R.T., Frazier, E.A., Cataldo, A.M., Simon, V.A., Spirito, A., \& Prinstein, M.J. (2014). Negative life events and non-suicidal self-injury in an adolescent inpatient sample. Archives of Suicide Research, 18, 251-258.

Lloyd-Richardson, E.E., Perrine, N., Dierker, L., \& Kelley, M.L. (2007). Characteristics and functions of non-suicidal self-injury in a community sample of adolescents. Psychological Medicine, 37, 1183-1192.

Miklósi, M., Martos, T., Kocsis-Bogár, K., \& Perczel-Forintos, D. (2011). A Kognitív ÉrzelemReguláció Kérdőív magyar változatának pszichometriai jellemzői. Psychiatria Hungarica, 26(2), 102-111.

Morales, J.M., \& Guarnero, P.A. (2014). Non-suicidal self-injury among adult males in a correctional setting. Issues in Mental Health Nursing, 35, 628-634.

Muris, P., Merckelbach, H., \& Peeters, E. (2003). The links between the Adolescent Dissociative Experiences Scale (A-DES), fantasy proneness, and anxiety symptoms. The Journal of Nervous and Mental Disease, 191, 18-24.

Nock, M.K., \& Prinstein, M.J. (2004). A functional approach to the assessment of selfmutilative behavior. Journal of Consulting and Clinical Psychology, 72, 885-890.

Nock, M.K., \& Prinstein, M.J. (2005). Contextual features and behavioral functions of selfmutilation among adolescents. Journal of Abnormal Psychology, 114, 140-146.

Nock, M.K., Joiner, T.E., Gordon, K.H., Lloyd-Richardson, E., \& Prinstein, M.J. (2006). Nonsuicidal self-injury among adolescents: Diagnostic correlates and relation to suicide attempts. Psychiatry Research, 144, 65-72.

Nock, M.K., Prinstein, M.J., \& Sterba, S.K. (2009). Revealing the form and function of selfinjurious thoughts and behaviors: A real-time ecological assessment study among adolescents and young adults. Journal of Abnormal Psychology, 118, 816-827.

Pattison, E.M., \& Kahan, J. (1983). The Deliberate Self-Harm Syndrome. American Journal of Psychiatry, 140(7), 867-872.

Pierce, C.A., Block, C.A., \& Aguinis, H. (2004). Cautionary note on reporting eta-squared values from multifactor anova designs. Educational and Psychological Measurement, 64(6), 916-924.

Power, J., Smith, H.P., \& Beaudette, J.N. (2016). Examining Nock and Prinstein's FourFunction Model with offenders who self-injure. Personality Disorders: Theory, Research, and Treatment, 7(3), 309-314.

Renshaw, T.L. (2016). Screening for psychological inflexibility: Initial validation of the Avoidance and Fusion Questionnaire for Youth as a school mental health screener. Journal of Psychoeducational Assessment, 1-12. Doi: 10.1177/0734282916644096

Rossouw, T., \& Fonagy, P. (2012). Mentalization-based treatment for self-harm in adolescents: A randomized controlled trial. Journal of the American Academy of Child and Adolescent Psychiatry, 51, 1304-1313.

Saraff, P.D., \& Pepper, C.M. (2014). Functions, lifetime frequency, and variety of methods of non-suicidal self-injury among college students. Psychiatry Research, 219(2), 298-304. 
Sansone, R.A., \& Sansone, L.A. (2010). Measuring self-harm behavior with the Self-Harm Inventory. Psychiatry, 7(4), 16-20.

Suyemoto, K.L. (1998). The functions of self-mutilation. Clinical Psychology Review, 18, 531-554.

Szemenyei, E., Reinhardt, M., Szabó, E., Szabó, K. G., Urbán, R., Harvey, S.T., et al. (2018). Measuring psychological inflexibility in children and adolescents: Evaluating the Avoidance and Fusion Questionnaire for Youth. Assessment, 1-11, Article ID 30198319. Doi: $10.1177 / 1073191118796558$

Vanderlinden, J., \& Vandereycken, W. (1997). Trauma, dissociation, and impulse dyscontrol in eating disorders. New York: Brunner-Mazel

Veague, H.B., Collins, C., \& Levitt, P. (2008). Cutting and self-harm. New York: Infobase Publishing

Victor, S.E., \& Klonsky, E.D. (2014). Correlates of suicide attempts among self-injurers: A meta-analysis. Clinical Psychology Review, 34, 282-297.

Washburn, J.J., Potthoff, L.M., Juzwin, K.R., \& Styer, D.M. (2015). Assessing DSM-5 nonsuicidal self-injury disorder in a clinical sample. Psychological Assessment, 27(1), 31-41.

Whiteside, S.P., \& Lynam, D.R. (2001). The Five Factor Model and impulsivity: Using a structural model of personality to understand impulsivity. Personality and Individual Differences, 30(4), 669-689.

World Health Organization (WHO) (2001). Declaration of Helsinki. Bulletin of the World Health Organization, 79(4), 373-374.

Zetterqvist, M. (2015). The DSM-5 diagnosis of nonsuicidal self-injury disorder: A review of the empirical literature. Child and Adolescent Psychiatry and Mental Health, 9:31.

Zelkowitz, R.L., Porter, A.C., Heiman, E.R., \& Cole, D.A. (2017). Social exposure and emotion dysregulation: Main effects in relation to nonsuicidal self-injury. Journal of Adolescence, 60, 94-103.

Zetterqvist, M., Lundh, L.G., Dahlström, Ö., \& Svedin, C.G. (2013). Prevalence and function of non-suicidal self-injury (NSSI) in a community sample of adolescents, using suggested DSM-5 criteria for a potential NSSI disorder. Journal of Abnormal Child Psychology, 41, 759-773.

\section{Köszönetnyilvánítás}

Reinhardt Melindát a Nemzeti Kutatási, Fejlesztési és Innovációs Hivatal - NKFIH a PD 128332 számú elnyert pályázat keretében támogatta. Kökönyei Gyöngyi a Nemzeti Kutatási, Fejlesztési és Innovációs Hivatal - NKFIH FK 128614 számú pályázatának keretében, illetve a Nemzeti Agykutatási Program (2017-1.2.1-NKP-2017-00002) keretében részesült támogatásban.

A szerzők továbbá köszönetüket fejezik ki Márton Blanka Anikónak az adatfelvétel során nyújtott jelentős segítségéért. 


\section{Szerzói munkamegosztás}

A kutatás szakmai keretét Reinhardt Melinda és Kökönyei Gyöngyi dolgozták ki. Az adatfelvételben Drubina Boglárka és Reinhardt Melinda vett részt a szerzők közül. Az adatelemzés Reinhardt Melinda és Horváth Zsolt munkája. A kéziratot Reinhardt Melinda készítette el, amit Kökönyei Gyöngyi, Drubina Boglárka és Horváth Zsolt kritikai megjegyzésekkel látott el, ennek alapján a fent nevezettek együttesen alakították ki a tanulmány végső változatát. A levelező szerző megerősíti, hogy fentebb felsorolt mindenkit, aki a tanulmány elkészültéhez érdemben hozzájárult.

\section{Nyilatkozat érdekütközésról}

A szerzők kijelentik, hogy egyikőjük esetében sem áll fenn érdekütközés.

\section{FÜGGELÉK \\ A Kezelésközpontú Önsértés Kérdőív (SIQ-TR-HU)}

Az önsértő viselkedés a saját test felületének különböző módú, szándékos, önmagunk által okozott megsértését jelenti (pl. saját magunk megvágása, megégetése), de mindez öngyilkossági szándék nélkül történik (azaz, aki ezt teszi, nem akar meghalni).

Ebben a kérdőívben ötféle önsértő viselkedésre kérdezünk rá: amikor valaki megkarmolja, megüti, megvágja, megégeti és/vagy megharapja magát.

Minden önsértő viselkedésformával kapcsolatban megkérdezzük, hogy tettél-e már olyat, és ha igen, akkor további információkat kérünk arról (pl. gyakorisága, átélt érzéseid, gondolataid stb.).

Ha előfordult, hogy olyan módon sértetted meg magad, amelyet nem soroltunk fel (pl. jelentősebb mennyiségú haj kitépése), akkor azt az utolsó oldalon leírhatod, részletezheted.

Köszönjük az együttmúködésed!

\section{A1 Mikor KARMOLTAD MEG magad szándékosan úgy utoljára, hogy az vérzett is?}
○ kevesebb, mint egy hete
( $\rightarrow$ ugorj az A2 kérdésre)
o egy hete
( $\rightarrow$ ugorj az A2 kérdésre)
o egy hónapja
o néhány hónapja
( $\rightarrow$ ugorj az A2 kérdésre)
o több mint egy éve
( $\rightarrow$ ugorj a B1 kérdésre)
o soha
( $\rightarrow$ ugorj a B1 kérdésre)
( $\rightarrow$ ugorj a B1 kérdésre) 
A2 Melyik testrészed/testrészeid sértetted meg így (karmolással) a legtöbbször?

(Több választás is lehetséges.)

$\circ$ fej, nyak

- karok, kezek, ujjak, körmök

o törzs, has, fenék

○ lábak, lábfej, talp, lábuijak

o mellek, nemi szervek

A3 Az elmúlt egy hónapban hány napon történt ilyen?

○ 1-5 nap között

○ 6-10 nap között

- 11-15 nap között

$\circ$ több mint 15 napon

A4 Egy nap alatt átlagban hányszor fordult mindez eló?

○ kevesebb mint egyszer egy nap / egyáltalán nem fordult elő

- 1-szer vagy 2-szer egy nap

- 3-szor vagy 4-szer egy nap

○ 5-ször vagy annál többször egy nap

A5 Milyen gyakran éreztél közben fájdalmat?
o soha
○ néha
- gyakran
$\circ$ mindig

A6 Mennyire (milyen mértékben) éreztél közben fájdalmat?

o semennyire

o enyhén

○ közepesen

o erősen

○ nagyon erősen

\begin{tabular}{|l|c|c|c|c|}
\hline \multicolumn{4}{|c|}{ A7 Amikor ezt tettem, akkor... } \\
\hline \multicolumn{1}{|c|}{ 1 = soha; 2 = néha; 3 = gyakran; 4 = mindig } \\
\hline Azt előre pontosan elterveztem. & 1 & 2 & 3 & 4 \\
\hline Tudatában voltam annak, hogy hogyan történt mindez. & 1 & 2 & 3 & 4 \\
\hline Elláttam a sebe(i)met. & 1 & 2 & 3 & 4 \\
\hline Eltitkoltam mindezt mások elől. & 1 & 2 & 3 & 4 \\
\hline
\end{tabular}


1 = egyáltalán nem; 2 = egy kicsit; 3 = közepesen $; 4$ = nagyon; 5 = nagyon-nagyon

\begin{tabular}{|l|c|c|c|c|c|}
\hline \multicolumn{5}{|c|}{ A8 Mit éreztél közvetlenül AZELÓTT, hogy ez megtörtént? } \\
\hline Boldogságot, örömöt & 1 & 2 & 3 & 4 & 5 \\
\hline Megkönnyebbülést & 1 & 2 & 3 & 4 & 5 \\
\hline Idegességet & 1 & 2 & 3 & 4 & 5 \\
\hline Unalmat & 1 & 2 & 3 & 4 & 5 \\
\hline Haragudtam magamra & 1 & 2 & 3 & 4 & 5 \\
\hline Haragudtam másokra & 1 & 2 & 3 & 4 & 5 \\
\hline Szorongást, aggodalmat & 1 & 2 & 3 & 4 & 5 \\
\hline Szomorúságot & 1 & 2 & 3 & 4 & 5 \\
\hline Búntudatot & 1 & 2 & 3 & 4 & 5 \\
\hline $\begin{array}{l}\text { Mást is éreztem (ha igen, írd le, mit): } \\
\text {........................... }\end{array}$ & 1 & 2 & 3 & 4 & 5 \\
\hline
\end{tabular}

\begin{tabular}{|l|c|c|c|c|c|}
\hline \multicolumn{7}{|c|}{ A9 Mit éreztél közvetlenül AZUTÁN, hogy ez megtörtént? } \\
\hline Boldogságot, örömöt & 1 & 2 & 3 & 4 & 5 \\
\hline Megkönnyebbülést & 1 & 2 & 3 & 4 & 5 \\
\hline Idegességet & 1 & 2 & 3 & 4 & 5 \\
\hline Unalmat & 1 & 2 & 3 & 4 & 5 \\
\hline Haragudtam magamra & 1 & 2 & 3 & 4 & 5 \\
\hline Haragudtam másokra & 1 & 2 & 3 & 4 & 5 \\
\hline Szorongást, aggodalmat & 1 & 2 & 3 & 4 & 5 \\
\hline Szomorúságot & 1 & 2 & 3 & 4 & 5 \\
\hline Búntudatot & 1 & 2 & 3 & 4 & 5 \\
\hline $\begin{array}{l}\text { Mást is éreztem (ha igen, írd le, mit): } \\
\text {.......................... }\end{array}$ & 1 & 2 & 3 & 4 & 5 \\
\hline
\end{tabular}

\section{A10 Miért csináltad mindezt? (Miért szoktad megkarmolni/megcsikarni magadat?)}

\begin{tabular}{|l|c|c|c|c|c|}
\hline Hogy némi örömöt érezzek & 1 & 2 & 3 & 4 & 5 \\
\hline $\begin{array}{l}\text { Hogy elkerüljem vagy elnyomjam a negatív } \\
\text { érzéseket }\end{array}$ & 1 & 2 & 3 & 4 & 5 \\
\hline $\begin{array}{l}\text { Hogy elkerüljem vagy elnyomjam a fájdalmas } \\
\text { gondolatokat vagy emlékeket }\end{array}$ & 1 & 2 & 3 & 4 & 5 \\
\hline
\end{tabular}




\begin{tabular}{|l|c|c|c|c|c|}
\hline \multicolumn{7}{|l|}{ A10 Miért csináltad mindezt? (Miért szoktad megkarmolni/megcsikarni magadat?) } \\
\hline $\begin{array}{l}\text { Hogy egy homályos, kábult vagy eltompult } \\
\text { állapotba kerüljek }\end{array}$ & 1 & 2 & 3 & 4 & 5 \\
\hline Hogy figyelmet kapjak másoktól & 1 & 2 & 3 & 4 & 5 \\
\hline $\begin{array}{l}\text { Hogy kimeneküljek egy homályos, kábult vagy } \\
\text { eltompult állapotból }\end{array}$ & 1 & 2 & 3 & 4 & 5 \\
\hline Hogy megbüntessem magam & 1 & 2 & 3 & 4 & 5 \\
\hline Hogy elcsúfítsam magam & 1 & 2 & 3 & 4 & 5 \\
\hline $\begin{array}{l}\text { Hogy elkerüljem vagy elnyomjam az öngyilkossági } \\
\text { gondolatokat }\end{array}$ & 1 & 2 & 3 & 4 & 5 \\
\hline $\begin{array}{l}\text { Hogy megmutassam magamnak, hogy milyen erős } \\
\text { vagyok }\end{array}$ & 1 & 2 & 3 & 4 & 5 \\
\hline $\begin{array}{l}\text { Hogy megmutassam másoknak, hogy milyen erós } \\
\text { vagyok }\end{array}$ & 1 & 2 & 3 & 4 & 5 \\
\hline $\begin{array}{l}\text { Hogy elkerüljem azt, hogy valami olyan } \\
\text { kellemetlen dolgot csináljak, amit nem akarok } \\
\text { megtenni }\end{array}$ & 1 & 2 & 3 & 4 & 5 \\
\hline $\begin{array}{l}\text { Hogy ne kelljen iskolába menni vagy dolgozni, } \\
\text { vagy valami mást csinálni }\end{array}$ & 1 & 2 & 3 & 4 & 5 \\
\hline Hogy ne kelljen másokkal együtt lennem & 1 & 2 & 3 & 4 & 5 \\
\hline $\begin{array}{l}\text { Más ok miatt tettem (írd ide, hogy miért): } \\
\text {........................ }\end{array}$ & 1 & 2 & 3 & 4 & 5 \\
\hline
\end{tabular}

\section{B1 Mikor ÜTÖTTED MEG magad szándékosan utoljára?}

$\circ$ kevesebb, mint egy hete

o egy hete

o egy hónapja

○ néhány hónapja

$(\rightarrow$ ugorj a B2 kérdésre)

$(\rightarrow$ ugorj a B2 kérdésre)

$(\rightarrow$ ugorj a B2 kérdésre)

o több mint egy éve

$(\rightarrow$ ugorj a $\mathrm{C} 1$ kérdésre)

o soha

$(\rightarrow$ ugorj a $\mathrm{C} 1$ kérdésre)

$(\rightarrow$ ugorj a C1 kérdésre)

\section{B2 Melyik testrészed/testrészeid sértetted meg így (hogy megütötted)}

\section{a legtöbbször?}

(Több választás is lehetséges.)

$\circ$ fej, nyak

○ karok, kezek, ujjak, körmök

o törzs, has, fenék 

○ lábak, lábfej, talp, lábujjak
o mellek, nemi szervek

B3 Az elmúlt egy hónapban hány napon történt ilyen?
○ 1-5 nap között
○ 6-10 nap között
○ 11-15 nap között
$\circ$ több mint 15 napon

B4 Egy nap alatt átlagban hányszor fordult mindez eló?

○ kevesebb mint egyszer egy nap / egyáltalán nem fordult elő

- 1-szer vagy 2-szer egy nap

○ 3-szor vagy 4-szer egy nap

○ 5-ször vagy annál többször egy nap

B5 Milyen gyakran éreztél közben fájdalmat?
o soha
○ néha
o gyakran
$\circ$ mindig

B6 Mennyire (milyen mértékben) éreztél közben fájdalmat?
o semennyire
○ enyhén
$\circ$ közepesen
$\circ$ erősen
○ nagyon erősen

\begin{tabular}{|l|c|c|c|c|}
\hline \multicolumn{4}{|c|}{ B7 Amikor ezt tettem, akkor... } \\
\hline \multicolumn{1}{|c|}{ 1 = soha; 2 = néha; 3 = gyakran; 4 = mindig } \\
\hline Azt előre pontosan elterveztem. & 1 & 2 & 3 & 4 \\
\hline Tudatában voltam annak, hogy hogyan történt mindez. & 1 & 2 & 3 & 4 \\
\hline Elláttam a sebe(i)met. & 1 & 2 & 3 & 4 \\
\hline Eltitkoltam mindezt mások elől. & 1 & 2 & 3 & 4 \\
\hline
\end{tabular}


1 = egyáltalán nem; 2 = egy kicsit; 3 = közepesen; 4 = nagyon; 5 = nagyon-nagyon

\begin{tabular}{|l|c|c|c|c|c|}
\hline \multicolumn{7}{|c|}{ B8 Mit éreztél közvetlenül AZELŐTT, hogy ez megtörtént? } \\
\hline Boldogságot, örömöt & 1 & 2 & 3 & 4 & 5 \\
\hline Megkönnyebbülést & 1 & 2 & 3 & 4 & 5 \\
\hline Idegességet & 1 & 2 & 3 & 4 & 5 \\
\hline Unalmat & 1 & 2 & 3 & 4 & 5 \\
\hline Haragudtam magamra & 1 & 2 & 3 & 4 & 5 \\
\hline Haragudtam másokra & 1 & 2 & 3 & 4 & 5 \\
\hline Szorongást, aggodalmat & 1 & 2 & 3 & 4 & 5 \\
\hline Szomorúságot & 1 & 2 & 3 & 4 & 5 \\
\hline Búntudatot & 1 & 2 & 3 & 4 & 5 \\
\hline $\begin{array}{l}\text { Mást is éreztem (ha igen, írd le, mit): } \\
\text {.......................... }\end{array}$ & 1 & 2 & 3 & 4 & 5 \\
\hline
\end{tabular}

\begin{tabular}{|l|c|c|c|c|c|}
\hline \multicolumn{5}{|c|}{ B9 Mit éreztél közvetlenül AZUTÁN, hogy ez megtörtént? } \\
\hline Boldogságot, örömöt & 1 & 2 & 3 & 4 & 5 \\
\hline Megkönnyebbülést & 1 & 2 & 3 & 4 & 5 \\
\hline Idegességet & 1 & 2 & 3 & 4 & 5 \\
\hline Unalmat & 1 & 2 & 3 & 4 & 5 \\
\hline Haragudtam magamra & 1 & 2 & 3 & 4 & 5 \\
\hline Haragudtam másokra & 1 & 2 & 3 & 4 & 5 \\
\hline Szorongást, aggodalmat & 1 & 2 & 3 & 4 & 5 \\
\hline Szomorúságot & 1 & 2 & 3 & 4 & 5 \\
\hline Búntudatot & 1 & 2 & 3 & 4 & 5 \\
\hline $\begin{array}{l}\text { Mást is éreztem (ha igen, írd le, mit): } \\
\text {........................... }\end{array}$ & 1 & 2 & 3 & 4 & 5 \\
\hline
\end{tabular}

\begin{tabular}{|l|c|c|c|c|c|}
\hline \multicolumn{7}{|c|}{ B10 Miért csináltad mindezt? (Miért szoktad megütni magadat?) } \\
\hline Hogy némi örömöt érezzek & 1 & 2 & 3 & 4 & 5 \\
\hline $\begin{array}{l}\text { Hogy elkerüljem vagy elnyomjam a negatív } \\
\text { érzéseket }\end{array}$ & 1 & 2 & 3 & 4 & 5 \\
\hline $\begin{array}{l}\text { Hogy elkerüljem vagy elnyomjam a fájdalmas } \\
\text { gondolatokat vagy emlékeket }\end{array}$ & 1 & 2 & 3 & 4 & 5 \\
\hline $\begin{array}{l}\text { Hogy egy homályos, kábult vagy eltompult } \\
\text { állapotba kerüljek }\end{array}$ & 1 & 2 & 3 & 4 & 5 \\
\hline
\end{tabular}




\begin{tabular}{|c|c|c|c|c|c|}
\hline \multicolumn{6}{|c|}{ B10 Miért csináltad mindezt? (Miért szoktad megütni magadat?) } \\
\hline Hogy figyelmet kapjak másoktól & 1 & 2 & 3 & 4 & 5 \\
\hline $\begin{array}{l}\text { Hogy kimeneküljek egy homályos, } \\
\text { kábult vagy eltompult állapotból }\end{array}$ & 1 & 2 & 3 & 4 & 5 \\
\hline Hogy megbüntessem magam & 1 & 2 & 3 & 4 & 5 \\
\hline Hogy elcsúfítsam magam & 1 & 2 & 3 & 4 & 5 \\
\hline $\begin{array}{l}\text { Hogy elkerüljem vagy elnyomjam } \\
\text { az öngyilkossági gondolatokat }\end{array}$ & 1 & 2 & 3 & 4 & 5 \\
\hline $\begin{array}{l}\text { Hogy megmutassam magamnak, } \\
\text { hogy milyen erős vagyok }\end{array}$ & 1 & 2 & 3 & 4 & 5 \\
\hline $\begin{array}{l}\text { Hogy megmutassam másoknak, } \\
\text { hogy milyen erős vagyok }\end{array}$ & 1 & 2 & 3 & 4 & 5 \\
\hline $\begin{array}{l}\text { Hogy elkerüljem azt, hogy valami olyan } \\
\text { kellemetlen dolgot csináljak, amit nem akarok } \\
\text { megtenni }\end{array}$ & 1 & 2 & 3 & 4 & 5 \\
\hline $\begin{array}{l}\text { Hogy ne kelljen iskolába menni vagy dolgozni, } \\
\text { vagy valami mást csinálni }\end{array}$ & 1 & 2 & 3 & 4 & 5 \\
\hline Hogy ne kelljen másokkal együtt lennem & 1 & 2 & 3 & 4 & 5 \\
\hline 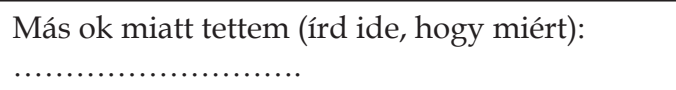 & 1 & 2 & 3 & 4 & 5 \\
\hline
\end{tabular}

\section{C1 Mikor VÁGTAD MEG magad szándékosan utoljára?}
$\circ$ kevesebb, mint egy hete
$(\rightarrow$ ugorj a C2 kérdésre)
$\circ$ egy hete
$(\rightarrow$ ugorj a C2 kérdésre)
- egy hónapja
$(\rightarrow$ ugorj a C2 kérdésre)
○ néhány hónapja
$(\rightarrow$ ugorj a D1 kérdésre)
○ több mint egy éve
$(\rightarrow$ ugorj a D1 kérdésre)
o soha
$(\rightarrow$ ugorj a D1 kérdésre)

\section{C2 Melyik testrészed/testrészeid sértetted meg így (megvágással) a legtöbbször? \\ (Több választás is lehetséges.) \\ $\circ$ fej, nyak \\ ○ karok, kezek, ujjak, körmök \\ ○ törzs, has, fenék \\ ○ lábak, lábfej, talp, lábujjak \\ o mellek, nemi szervek}


C3 Az elmúlt egy hónapban hány napon történt ilyen?
○ 1-5 nap között
○ 6-10 nap között
- 11-15 nap között
$\circ$ több mint 15 napon

C4 Egy nap alatt átlagban hányszor fordult mindez eló?

- kevesebb mint egyszer egy nap / egyáltalán nem fordult eló

- 1-szer vagy 2-szer egy nap

○ 3-szor vagy 4-szer egy nap

○ 5-ször vagy annál többször egy nap

C5 Milyen gyakran éreztél közben fájdalmat?
o soha
○ néha
o gyakran
$\circ$ mindig

C6 Mennyire (milyen mértékben) éreztél közben fájdalmat?

o semennyire

o enyhén

○ közepesen

$\circ$ erősen

○ nagyon erősen

\begin{tabular}{|l|c|c|c|c|}
\hline \multicolumn{4}{|c|}{ C7 Amikor ezt tettem, akkor... } \\
\hline \multicolumn{1}{|c|}{ 1 = soha; 2 = néha; 3 = gyakran; 4 = mindig } \\
\hline Azt előre pontosan elterveztem. & 1 & 2 & 3 & 4 \\
\hline Tudatában voltam annak, hogy hogyan történt mindez. & 1 & 2 & 3 & 4 \\
\hline Elláttam a sebe(i)met. & 1 & 2 & 3 & 4 \\
\hline Eltitkoltam mindezt mások elől. & 1 & 2 & 3 & 4 \\
\hline
\end{tabular}

1 = egyáltalán nem; 2 = egy kicsit; 3 = közepesen 4 = nagyon; 5 = nagyon-nagyon

\begin{tabular}{|l|c|c|c|c|c|}
\hline \multicolumn{5}{|c|}{ C8 Mit éreztél közvetlenül AZELÓTT, hogy ez megtörtént? } \\
\hline Boldogságot, örömöt & 1 & 2 & 3 & 4 & 5 \\
\hline Megkönnyebbülést & 1 & 2 & 3 & 4 & 5 \\
\hline Idegességet & 1 & 2 & 3 & 4 & 5 \\
\hline
\end{tabular}




\begin{tabular}{|l|c|c|c|c|c|}
\hline \multicolumn{5}{|c|}{ C8 Mit éreztél közvetlenül AZELŐTT, hogy ez megtörtént? } \\
\hline Unalmat & 1 & 2 & 3 & 4 & 5 \\
\hline Haragudtam magamra & 1 & 2 & 3 & 4 & 5 \\
\hline Haragudtam másokra & 1 & 2 & 3 & 4 & 5 \\
\hline Szorongást, aggodalmat & 1 & 2 & 3 & 4 & 5 \\
\hline Szomorúságot & 1 & 2 & 3 & 4 & 5 \\
\hline Búntudatot & 1 & 2 & 3 & 4 & 5 \\
\hline Mást is éreztem (ha igen, írd le, mit):.......................... & 1 & 2 & 3 & 4 & 5 \\
\hline
\end{tabular}

\begin{tabular}{|l|c|c|c|c|c|}
\hline \multicolumn{5}{|c|}{ C9 Mit éreztél közvetlenül AZUTÁN, hogy ez megtörtént? } \\
\hline Boldogságot, örömöt & 1 & 2 & 3 & 4 & 5 \\
\hline Megkönnyebbülést & 1 & 2 & 3 & 4 & 5 \\
\hline Idegességet & 1 & 2 & 3 & 4 & 5 \\
\hline Unalmat & 1 & 2 & 3 & 4 & 5 \\
\hline Haragudtam magamra & 1 & 2 & 3 & 4 & 5 \\
\hline Haragudtam másokra & 1 & 2 & 3 & 4 & 5 \\
\hline Szorongást, aggodalmat & 1 & 2 & 3 & 4 & 5 \\
\hline Szomorúságot & 1 & 2 & 3 & 4 & 5 \\
\hline Búntudatot & 1 & 2 & 3 & 4 & 5 \\
\hline Mást is éreztem (ha igen, írd le, mit):......................... & 1 & 2 & 3 & 4 & 5 \\
\hline
\end{tabular}

\begin{tabular}{|l|c|c|c|c|c|}
\hline \multicolumn{7}{|c|}{ C10 Miért csináltad mindezt? (Miért szoktad megvágni magadat?) } \\
\hline Hogy némi örömöt érezzek & 1 & 2 & 3 & 4 & 5 \\
\hline Hogy elkerüljem vagy elnyomjam a negatív érzéseket & 1 & 2 & 3 & 4 & 5 \\
\hline $\begin{array}{l}\text { Hogy elkerüljem vagy elnyomjam a fájdalmas gondolatokat } \\
\text { vagy emlékeket }\end{array}$ & 1 & 2 & 3 & 4 & 5 \\
\hline Hogy egy homályos, kábult vagy eltompult állapotba kerüljek & 1 & 2 & 3 & 4 & 5 \\
\hline Hogy figyelmet kapjak másoktól & 1 & 2 & 3 & 4 & 5 \\
\hline $\begin{array}{l}\text { Hogy kimeneküljek egy homályos, kábult vagy eltompult } \\
\text { allapotból }\end{array}$ & 1 & 2 & 3 & 4 & 5 \\
\hline Hogy megbüntessem magam & 1 & 2 & 3 & 4 & 5 \\
\hline Hogy elcsúfítsam magam & 1 & 2 & 3 & 4 & 5 \\
\hline
\end{tabular}




\begin{tabular}{|l|l|l|l|l|l|}
\hline \multicolumn{7}{|c|}{ C10 Miért csináltad mindezt? (Miért szoktad megvágni magadat?) } \\
\hline $\begin{array}{l}\text { Hogy elkerüljem vagy elnyomjam az öngyilkossági } \\
\text { gondolatokat }\end{array}$ & 1 & 2 & 3 & 4 & 5 \\
\hline Hogy megmutassam magamnak, hogy milyen erós vagyok & 1 & 2 & 3 & 4 & 5 \\
\hline Hogy megmutassam másoknak, hogy milyen erós vagyok & 1 & 2 & 3 & 4 & 5 \\
\hline $\begin{array}{l}\text { Hogy elkerüljem azt, hogy valami olyan kellemetlen dolgot } \\
\text { csináljak, amit nem akarok megtenni }\end{array}$ & 1 & 2 & 3 & 4 & 5 \\
\hline $\begin{array}{l}\text { Hogy ne kelljen iskolába menni vagy dolgozni, } \\
\text { vagy valami mást csinálni }\end{array}$ & 1 & 2 & 3 & 4 & 5 \\
\hline Hogy ne kelljen másokkal együtt lennem & 1 & 2 & 3 & 4 & 5 \\
\hline Más ok miatt tettem (írd ide, hogy miért): ........................... & 1 & 2 & 3 & 4 & 5 \\
\hline
\end{tabular}

D1 Mikor ÉGETTED MEG magad szándékosan utoljára?
$\circ$ kevesebb, mint egy hete
$(\rightarrow$ ugorj a D2 kérdésre)
o egy hete
- egy hónapja
$(\rightarrow$ ugorj a D2 kérdésre)
○ néhány hónapja
$(\rightarrow$ ugorj a D2 kérdésre)
o több mint egy éve
$(\rightarrow$ ugorj az E1 kérdésre)
o soha
( $\rightarrow$ ugorj az E1 kérdésre)
$(\rightarrow$ ugorj az E1 kérdésre)

\section{D2 Melyik testrészed/testrészeid sértetted meg így (megégetéssel)}

\section{a legtöbbször?}

(Több választás is lehetséges.)

$\circ$ fej, nyak

○ karok, kezek, ujjak, körmök

○ törzs, has, fenék

○ lábak, lábfej, talp, lábujjak

o mellek, nemi szervek

\section{D3 Az elmúlt egy hónapban hány napon történt ilyen?}
○ 1-5 nap között
○ 6-10 nap között
○ 11-15 nap között
$\circ$ több mint 15 napon

\section{D4 Egy nap alatt átlagban hányszor fordult mindez elö?}
- kevesebb mint egyszer egy nap / egyáltalán nem fordult eló
- 1-szer vagy 2-szer egy nap
○ 3-szor vagy 4-szer egy nap
○ 5-ször vagy annál többször egy nap 


\section{D5 Milyen gyakran éreztél közben fájdalmat? \\ o soha \\ ○ néha \\ o gyakran \\ $\circ$ mindig}

D6 Mennyire (milyen mértékben) éreztél közben fájdalmat?

o semennyire

- enyhén

○ közepesen

o erősen

○ nagyon erősen

\begin{tabular}{|l|c|c|c|c|}
\hline \multicolumn{5}{|c|}{ D7 Amikor ezt tettem, akkor... } \\
\hline \multicolumn{1}{|c|}{ 1 = soha; 2 = néha; 3 = gyakran; 4 = mindig } \\
\hline Azt előre pontosan elterveztem. & 1 & 2 & 3 & 4 \\
\hline Tudatában voltam annak, hogy hogyan történt mindez. & 1 & 2 & 3 & 4 \\
\hline Elláttam a sebe(i)met. & 1 & 2 & 3 & 4 \\
\hline Eltitkoltam mindezt mások elől. & 1 & 2 & 3 & 4 \\
\hline
\end{tabular}

1 = egyáltalán nem; 2 = egy kicsit; 3 = közepesen 4 = nagyon; 5 = nagyon-nagyon

\begin{tabular}{|l|c|c|c|c|c|}
\hline \multicolumn{5}{|c|}{ D8 Mit éreztél közvetlenül AZELŐTT, hogy ez megtörtént? } \\
\hline Boldogságot, örömöt & 1 & 2 & 3 & 4 & 5 \\
\hline Megkönnyebbülést & 1 & 2 & 3 & 4 & 5 \\
\hline Idegességet & 1 & 2 & 3 & 4 & 5 \\
\hline Unalmat & 1 & 2 & 3 & 4 & 5 \\
\hline Haragudtam magamra & 1 & 2 & 3 & 4 & 5 \\
\hline Haragudtam másokra & 1 & 2 & 3 & 4 & 5 \\
\hline Szorongást, aggodalmat & 1 & 2 & 3 & 4 & 5 \\
\hline Szomorúságot & 1 & 2 & 3 & 4 & 5 \\
\hline Búntudatot & 1 & 2 & 3 & 4 & 5 \\
\hline Mást is éreztem (ha igen, írd le, mit):.......................... & 1 & 2 & 3 & 4 & 5 \\
\hline
\end{tabular}




\begin{tabular}{|l|c|c|c|c|c|}
\hline \multicolumn{5}{|c|}{ D9 Mit éreztél közvetlenül AZUTÁN, hogy ez megtörtént? } \\
\hline Boldogságot, örömöt & 1 & 2 & 3 & 4 & 5 \\
\hline Megkönnyebbülést & 1 & 2 & 3 & 4 & 5 \\
\hline Idegességet & 1 & 2 & 3 & 4 & 5 \\
\hline Unalmat & 1 & 2 & 3 & 4 & 5 \\
\hline Haragudtam magamra & 1 & 2 & 3 & 4 & 5 \\
\hline Haragudtam másokra & 1 & 2 & 3 & 4 & 5 \\
\hline Szorongást, aggodalmat & 1 & 2 & 3 & 4 & 5 \\
\hline Szomorúságot & 1 & 2 & 3 & 4 & 5 \\
\hline Búntudatot & 1 & 2 & 3 & 4 & 5 \\
\hline Mást is éreztem (ha igen, írd le, mit):.................................... & 1 & 2 & 3 & 4 & 5 \\
\hline
\end{tabular}

\begin{tabular}{|l|c|c|c|c|c|}
\hline \multicolumn{5}{|c|}{ D10 Miért csináltad mindezt? (Miért szoktad megégetni magadat?) } \\
\hline Hogy némi örömöt érezzek & 1 & 2 & 3 & 4 & 5 \\
\hline Hogy elkerüljem vagy elnyomjam a negatív érzéseket & 1 & 2 & 3 & 4 & 5 \\
\hline $\begin{array}{l}\text { Hogy elkerüljem vagy elnyomjam a fájdalmas gondolatokat } \\
\text { vagy emlékeket }\end{array}$ & 1 & 2 & 3 & 4 & 5 \\
\hline $\begin{array}{l}\text { Hogy egy homályos, kábult vagy eltompult állapotba } \\
\text { kerüljek }\end{array}$ & 1 & 2 & 3 & 4 & 5 \\
\hline Hogy figyelmet kapjak másoktól & 1 & 2 & 3 & 4 & 5 \\
\hline $\begin{array}{l}\text { Hogy kimeneküljek egy homályos, kábult vagy eltompult } \\
\text { állapotból }\end{array}$ & 1 & 2 & 3 & 4 & 5 \\
\hline Hogy megbüntessem magam & 1 & 2 & 3 & 4 & 5 \\
\hline Hogy elcsúfítsam magam & 1 & 2 & 3 & 4 & 5 \\
\hline $\begin{array}{l}\text { Hogy elkerüljem vagy elnyomjam az öngyilkossági } \\
\text { gondolatokat }\end{array}$ & 1 & 2 & 3 & 4 & 5 \\
\hline Hogy megmutassam magamnak, hogy milyen erós vagyok & 1 & 2 & 3 & 4 & 5 \\
\hline $\begin{array}{l}\text { Hogy megmutassam másoknak, hogy milyen erós vagyok } \\
\text { Hogy elkerüljem azt, hogy valami olyan kellemetlen dolgot } \\
\text { csináljak, amit nem akarok megtenni }\end{array}$ & 1 & 2 & 3 & 4 & 5 \\
\hline $\begin{array}{l}\text { Hogy ne kelljen iskolába menni vagy dolgozni, vagy valami } \\
\text { mást csinálni }\end{array}$ & 1 & 2 & 3 & 4 & 5 \\
\hline Hogy ne kelljen másokkal együtt lennem & 1 & 2 & 3 & 4 & 5 \\
\hline $\begin{array}{l}\text { Más ok miatt tettem (írd ide, hogy miért): } \\
\text { H................... }\end{array}$ & 2 & 3 & 4 & 5 \\
\hline
\end{tabular}


E1 Mikor HARAPTAD MEG magad szándékosan utoljára?

$\circ$ kevesebb, mint egy hete ( $\rightarrow$ ugorj az E2 kérdésre)

o egy hete $(\rightarrow$ ugorj az E2 kérdésre)

- egy hónapja ( $\rightarrow$ ugorj az E2 kérdésre)

○ néhány hónapja ( $\rightarrow$ ugorj az F1 kérdésre)

$\circ$ több mint egy éve ( $\rightarrow$ ugorj az F1 kérdésre)

o soha ( $\rightarrow$ ugorj az F1 kérdésre)

E2 Melyik testrészed/testrészeid sértetted meg így (megharapással) a legtöbbször?

(Több választás is lehetséges.)

○ fej, nyak

○ karok, kezek, ujjak, körmök

○ törzs, has, fenék

○ lábak, lábfej, talp, lábujjak

o mellek, nemi szervek

E3 Az elmúlt egy hónapban hány napon történt ilyen?
○ 1-5 nap között
○ 6-10 nap között
○ 11-15 nap között
$\circ$ több mint 15 napon

E4 Egy nap alatt átlagban hányszor fordult mindez eló?

○ kevesebb mint egyszer egy nap / egyáltalán nem fordult elő

$\circ$ 1-szer vagy 2-szer egy nap

○ 3-szor vagy 4-szer egy nap

○ 5-ször vagy annál többször egy nap

E5 Milyen gyakran éreztél közben fájdalmat?

o soha

○ néha

o gyakran

$\circ$ mindig

E6 Mennyire (milyen mértékben) éreztél közben fájdalmat?
o semennyire
○ enyhén
$\circ$ közepesen
$\circ$ erősen
$\circ$ nagyon erősen 


\begin{tabular}{|l|c|c|c|c|}
\hline \multicolumn{4}{|c|}{ E7 Amikor ezt tettem, akkor... } \\
\hline \multicolumn{1}{|c|}{1 = soha; 2 = néha; 3 = gyakran; 4 = mindig } \\
\hline Azt előre pontosan elterveztem. & 1 & 2 & 3 & 4 \\
\hline Tudatában voltam annak, hogy hogyan történt mindez. & 1 & 2 & 3 & 4 \\
\hline Elláttam a sebe(i)met. & 1 & 2 & 3 & 4 \\
\hline Eltitkoltam mindezt mások elől. & 1 & 2 & 3 & 4 \\
\hline
\end{tabular}

1 = Egyáltalán nem; 2 = Egy kicsit; 3 = Közepesen $; 4=$ Nagyon $; 5=$ Nagyon-nagyon

\begin{tabular}{|l|c|c|c|c|c|}
\hline \multicolumn{5}{|c|}{ E8 Mit éreztél közvetlenül AZELÖTT, hogy ez megtörtént? } \\
\hline Boldogságot, örömöt & 1 & 2 & 3 & 4 & 5 \\
\hline Megkönnyebbülést & 1 & 2 & 3 & 4 & 5 \\
\hline Idegességet & 1 & 2 & 3 & 4 & 5 \\
\hline Unalmat & 1 & 2 & 3 & 4 & 5 \\
\hline Haragudtam magamra & 1 & 2 & 3 & 4 & 5 \\
\hline Haragudtam másokra & 1 & 2 & 3 & 4 & 5 \\
\hline Szorongást, aggodalmat & 1 & 2 & 3 & 4 & 5 \\
\hline Szomorúságot & 1 & 2 & 3 & 4 & 5 \\
\hline Búntudatot & 1 & 2 & 3 & 4 & 5 \\
\hline Mást is éreztem (ha igen, írd le, mit):......................... & 1 & 2 & 3 & 4 & 5 \\
\hline
\end{tabular}

\begin{tabular}{|l|c|c|c|c|c|}
\hline \multicolumn{5}{|c|}{ E9 Mit éreztél közvetlenül AZUTÁN, hogy ez megtörtént? } \\
\hline Boldogságot, örömöt & 1 & 2 & 3 & 4 & 5 \\
\hline Megkönnyebbülést & 1 & 2 & 3 & 4 & 5 \\
\hline Idegességet & 1 & 2 & 3 & 4 & 5 \\
\hline Unalmat & 1 & 2 & 3 & 4 & 5 \\
\hline Haragudtam magamra & 1 & 2 & 3 & 4 & 5 \\
\hline Haragudtam másokra & 1 & 2 & 3 & 4 & 5 \\
\hline Szorongást, aggodalmat & 1 & 2 & 3 & 4 & 5 \\
\hline Szomorúságot & 1 & 2 & 3 & 4 & 5 \\
\hline Búntudatot & 1 & 2 & 3 & 4 & 5 \\
\hline Mást is éreztem (ha igen, írd le, mit): ......................... & 1 & 2 & 3 & 4 & 5 \\
\hline
\end{tabular}




\begin{tabular}{|l|c|c|c|c|c|}
\hline \multicolumn{5}{|c}{ E10 Miért csináltad mindezt? (Miért szoktad megharapni magadat?) } \\
\hline Hogy némi örömöt érezzek & 1 & 2 & 3 & 4 & 5 \\
\hline Hogy elkerüljem vagy elnyomjam a negatív érzéseket & 1 & 2 & 3 & 4 & 5 \\
\hline $\begin{array}{l}\text { Hogy elkerüljem vagy elnyomjam a fájdalmas gondolatokat } \\
\text { vagy emlékeket }\end{array}$ & 1 & 2 & 3 & 4 & 5 \\
\hline Hogy egy homályos, kábult vagy eltompult állapotba kerüljek & 1 & 2 & 3 & 4 & 5 \\
\hline Hogy figyelmet kapjak másoktól & 1 & 2 & 3 & 4 & 5 \\
\hline $\begin{array}{l}\text { Hogy kimeneküljek egy homályos, kábult vagy eltompult } \\
\text { álapotból }\end{array}$ & 1 & 2 & 3 & 4 & 5 \\
\hline Hogy megbüntessem magam & 1 & 2 & 3 & 4 & 5 \\
\hline Hogy elcsúfítsam magam & 1 & 2 & 3 & 4 & 5 \\
\hline $\begin{array}{l}\text { Hogy elkerüljem vagy elnyomjam az öngyilkossági } \\
\text { gondolatokat }\end{array}$ & 1 & 2 & 3 & 4 & 5 \\
\hline Hogy megmutassam magamnak, hogy milyen erós vagyok & 1 & 2 & 3 & 4 & 5 \\
\hline Hogy megmutassam másoknak, hogy milyen erós vagyok & 1 & 2 & 3 & 4 & 5 \\
\hline $\begin{array}{l}\text { Hogy elkerüljem azt, hogy valami olyan kellemetlen dolgot } \\
\text { csináljak, amit nem akarok megtenni }\end{array}$ & 1 & 2 & 3 & 4 & 5 \\
\hline $\begin{array}{l}\text { Hogy ne kelljen iskolába menni vagy dolgozni, vagy valami } \\
\text { mást csinálni }\end{array}$ & 1 & 2 & 3 & 4 & 5 \\
\hline Hogy ne kelljen másokkal együtt lennem & 1 & 2 & 3 & 4 & 5 \\
\hline $\begin{array}{l}\text { Más ok miatt tettem (írd ide, hogy miért): } \\
\text { H....................... }\end{array}$ & 2 & 3 & 4 & 5 \\
\hline
\end{tabular}

Okoztál-e MÁS FORMÁBAN magadnak sérülést? Ha igen, írd ide, hogyan:

\section{F1 Mikor csináltál ilyet szándékosan utoljára?}
$\circ$ kevesebb, mint egy hete
( $\rightarrow$ ugorj az F2 kérdésre)
o egy hete
$(\rightarrow$ ugorj az F2 kérdésre)
o egy hónapja
$(\rightarrow$ ugorj az F2 kérdésre)
○ néhány hónapja
$(\rightarrow$ vége a kérdőívnek)
o több mint egy éve
( $\rightarrow$ vége a kérdőívnek) 
F2 Melyik testrészed/testrészeid sértetted meg így a legtöbbször? (Több választás is lehetséges.)

$\circ$ fej, nyak

○ karok, kezek, ujjak, körmök

○ törzs, has, fenék

- lábak, lábfej, talp, lábujjak

o mellek, nemi szervek

F3 Az elmúlt egy hónapban hány napon történt ilyen?
○ 1-5 nap között
- 6-10 nap között
- 11-15 nap között
$\circ$ több mint 15 napon

F4 Egy nap alatt átlagban hányszor fordult mindez eló?

○ kevesebb mint egyszer egy nap / egyáltalán nem fordult eló

- 1-szer vagy 2-szer egy nap

○ 3-szor vagy 4-szer egy nap

○ 5-ször vagy annál többször egy nap

F5 Milyen gyakran éreztél közben fájdalmat?
o soha
○ néha
o gyakran
$\circ$ mindig

F6 Mennyire (milyen mértékben) éreztél közben fájdalmat?

o semennyire

o enyhén

○ közepesen

o erősen

○ nagyon erősen

\begin{tabular}{|l|c|c|c|c|}
\hline \multicolumn{5}{|c|}{ F7 Amikor ezt tettem, akkor... } \\
\hline \multicolumn{4}{|c|}{ 1 = soha; 2 = néha; 3 = gyakran; 4 = mindig } \\
\hline Azt előre pontosan elterveztem. & 1 & 2 & 3 & 4 \\
\hline Tudatában voltam annak, hogy hogyan történt mindez. & 1 & 2 & 3 & 4 \\
\hline Elláttam a sebe(i)met. & 1 & 2 & 3 & 4 \\
\hline Eltitkoltam mindezt mások elől. & 1 & 2 & 3 & 4 \\
\hline
\end{tabular}


1 = egyáltalán nem; 2 = egy kicsit; 3 = közepesen; 4 = nagyon; 5 = nagyon-nagyon

\begin{tabular}{|l|c|c|c|c|c|}
\hline \multicolumn{5}{|c|}{ F8 Mit éreztél közvetlenül AZELÖTT, hogy ez megtörtént? } \\
\hline Boldogságot, örömöt & 1 & 2 & 3 & 4 & 5 \\
\hline Megkönnyebbülést & 1 & 2 & 3 & 4 & 5 \\
\hline Idegességet & 1 & 2 & 3 & 4 & 5 \\
\hline Unalmat & 1 & 2 & 3 & 4 & 5 \\
\hline Haragudtam magamra & 1 & 2 & 3 & 4 & 5 \\
\hline Haragudtam másokra & 1 & 2 & 3 & 4 & 5 \\
\hline Szorongást, aggodalmat & 1 & 2 & 3 & 4 & 5 \\
\hline Szomorúságot & 1 & 2 & 3 & 4 & 5 \\
\hline Búntudatot & 1 & 2 & 3 & 4 & 5 \\
\hline Mást is éreztem (ha igen, írd le, mit):.......................... & 1 & 2 & 3 & 4 & 5 \\
\hline
\end{tabular}

\begin{tabular}{|l|c|c|c|c|c|}
\hline \multicolumn{5}{|c|}{ F9 Mit éreztél közvetlenül AZUTÁN, hogy ez megtörtént? } \\
\hline Boldogságot, örömöt & 1 & 2 & 3 & 4 & 5 \\
\hline Megkönnyebbülést & 1 & 2 & 3 & 4 & 5 \\
\hline Idegességet & 1 & 2 & 3 & 4 & 5 \\
\hline Unalmat & 1 & 2 & 3 & 4 & 5 \\
\hline Haragudtam magamra & 1 & 2 & 3 & 4 & 5 \\
\hline Haragudtam másokra & 1 & 2 & 3 & 4 & 5 \\
\hline Szorongást, aggodalmat & 1 & 2 & 3 & 4 & 5 \\
\hline Szomorúságot & 1 & 2 & 3 & 4 & 5 \\
\hline Búntudatot & 1 & 2 & 3 & 4 & 5 \\
\hline Mást is éreztem (ha igen, írd le, mit):......................... & 1 & 2 & 3 & 4 & 5 \\
\hline
\end{tabular}

\begin{tabular}{|l|c|c|c|c|c|}
\hline \multicolumn{5}{|c|}{ F10 Miért csináltad mindezt? } \\
\hline Hogy némi örömöt érezzek & 1 & 2 & 3 & 4 & 5 \\
\hline Hogy elkerüljem vagy elnyomjam a negatív érzéseket & 1 & 2 & 3 & 4 & 5 \\
\hline $\begin{array}{l}\text { Hogy elkerüljem vagy elnyomjam a fájdalmas gondolatokat } \\
\text { vagy emlékeket }\end{array}$ & 1 & 2 & 3 & 4 & 5 \\
\hline Hogy egy homályos, kábult vagy eltompult állapotba kerüljek & 1 & 2 & 3 & 4 & 5 \\
\hline Hogy figyelmet kapjak másoktól & 1 & 2 & 3 & 4 & 5 \\
\hline
\end{tabular}




\begin{tabular}{|l|c|c|c|c|c|}
\hline \multicolumn{5}{|c|}{ F10 Miért csináltad mindezt? } \\
\hline $\begin{array}{l}\text { Hogy kimeneküljek egy homályos, kábult vagy eltompult } \\
\text { állapotból }\end{array}$ & 1 & 2 & 3 & 4 & 5 \\
\hline Hogy megbüntessem magam & 1 & 2 & 3 & 4 & 5 \\
\hline Hogy elcsúfítsam magam & 1 & 2 & 3 & 4 & 5 \\
\hline Hogy elkerüljem vagy elnyomjam az öngyilkossági gondolatokat & 1 & 2 & 3 & 4 & 5 \\
\hline Hogy megmutassam magamnak, hogy milyen erós vagyok & 1 & 2 & 3 & 4 & 5 \\
\hline Hogy megmutassam másoknak, hogy milyen erós vagyok & 1 & 2 & 3 & 4 & 5 \\
\hline $\begin{array}{l}\text { Hogy elkerüljem azt, hogy valami olyan kellemetlen dolgot } \\
\text { csináljak, amit nem akarok megtenni }\end{array}$ & 1 & 2 & 3 & 4 & 5 \\
\hline $\begin{array}{l}\text { Hogy ne kelljen iskolába menni vagy dolgozni, vagy valami mást } \\
\text { csinálni }\end{array}$ & 1 & 2 & 3 & 4 & 5 \\
\hline Hogy ne kelljen másokkal együtt lennem & 1 & 2 & 3 & 4 & 5 \\
\hline Más ok miatt tettem (írd ide, hogy miért): ........................... & 1 & 2 & 3 & 4 & 5 \\
\hline
\end{tabular}

\title{
Complex evaluation of non-suicidal self-injury - Hungarian adaptation of the Self-Injury Questionnaire- Treatment Related (SIQ-TR)
}

\author{
REINHARDT, MELINDA - DRUBINA, BOGLÁRKA - \\ HORVÁTH, ZSOLT - KÖKÖNYEI, GYÖNGYI
}

Background: Non-suicidal self-injury (e.g., deliberate cutting, bruising, biting of the own body) is an increasing behavioral and health problem among adolescents. Several measurements published for the evaluation of self-harm, but only few questionnaires exist, which can capture the phenomenon in its complexity. Aims: Our current study aims to introduce the Self-Injury Questionnaire-Treatment Related (SIQ-TR) into the Hungarian test system, which can assess different forms of deliberate self-harm in several aspects (e.g., affective antecedents and consequences or functions of self-harm). Methods: Psychometric properties of the Hungarian version of the SIQ-TR were evaluated in a special population, among juvenile delinquents $\left(N=244 ; 92.6 \%\right.$ was boy; $\mathrm{M}_{\text {age }}=16.99$ years, $\mathrm{SD}=1.28$ years $)$. In association with self-harm we measured negative life events (Adolescent Life Event Questionnaire), as well as avoidance-focused emotion regulation processes (Avoidance and Fusion Questionnaire for Youth; Adolescent Dissociative Experience Scale). Results: Twenty-six percent $(26.2 \%)$ of the juvenile delinquents reported current self-harm behavior in the past month. Of those who reported self-harm, 34.4\% $(N=84)$ had been involved with NSSI prior to the past month, whereas $39.3 \%(N=96)$ had never previously engaged in self-harm. According to our results, the highest attention to the self-harm process and to wound care, as well as the most negative emotions are associated to scratching and biting. 
Furthermore, these two types of self-harm behavior have dominantly the function of reducing negative emotional states. Among juvenile delinquents current and past selfinjurers experienced significantly more stressful life events during the past six months compared with adolescents who have never self-harmed $(F(2)=9.16, p<0.0001)$. Moreover, current self-injurers can be featured with the highest dissociation $(F(2)=7.82, p=0.001)$ and cognitive inflexibility levels $(F(2)=6.58, p=0.002)$. Conclusions: Hungarian version of the SIQ-TR is an effective measure to investigate in the complexity of non-suicidal selfinjury behaviors. In this context, the measurement could establish targeted therapeutic interventions.

Keywords: non-suicidal self-injury; Self-Injury Questionnaire-Treatment Related; questionnaire adaptation; psychometric features; juvenile delinquents

A cikk a Creative Commons Attribution 4.0 International License (https:/ / creativecommons.org/ licenses/by/4.0/) feltételei szerint publikált Open Access közlemény, melynek szellemében a cikk bármilyen médiumban szabadon felhasználható, megosztható és újraközölhető, feltéve, hogy az eredeti szerzó és a közlés helye, illetve a CC License linkje és az esetlegesen végrehajtott módosítások feltüntetésre kerülnek. (SID_1) 